\title{
Mapping of GIS-Flood Hazard Using the Geomorphometric-Hazard Model: Case Study of the Al-Shamal Train Pathway in the City of Qurayyat, Kingdom of Saudi Arabia
}

\author{
Ashraf Abdelkarim 1,*(D), Seham S. Al-Alola ${ }^{2}$, Haya M. Alogayell ${ }^{2}$, Soha A. Mohamed ${ }^{3} \oplus$, \\ Ibtesam I. Alkadi ${ }^{2}$ and Ismail Y. Youssef 4 \\ 1 Research Center, Ministry of Housing, Riyadh 11461, Saudi Arabia \\ 2 Geography Department, College of Arts, Princess Nourah Bint Abdulrahman University, \\ Riyadh 84428, Saudi Arabia; Seham.alalola@gmail.com (S.S.A.-A.); hayaalogayell@gmail.com (H.M.A.); \\ Ebtesam.K@gmail.Com (I.I.A.) \\ 3 The High Institute of Tourism, Hotels and Computer (H.I.T.H.C.), The Ministry of Higher Education and \\ Scientific Research (MHESR), Alexandria 21500, Egypt; igsr.soha.ahmed@alexu.edu.eg \\ 4 Department of Geography, Faculty of Art, Monofiya University, Shbeen El Koom 32511, Egypt; \\ youssefegyptgeo@gmail.com \\ * Correspondence: dr.ashrafgis2020@gmail.com
}

Received: 20 July 2020; Accepted: 21 August 2020; Published: 22 August 2020

\begin{abstract}
Drainage basins in dry and semiarid environments are exposed to sudden, irregular flooding that poses a threat to urban areas and infrastructure. The associated risk is exacerbated by land use changes. Geomorphometric analyses of drainage basins based on geographic information systems (GIS) are essential tools for assessing conceptual flood hazards. Geomorphological data extracted from high-precision digital elevation models (DEMs) provide valuable information for modeling the geomorphic, surface classifications of the earth, and for flood hazard mapping. This study aimed to develop an integrative approach to the mapping of flood hazards along the Al-Shamal train pathway in the city of Qurayyat in the Kingdom of Saudi Arabia (KSA) using GIS and hazard modeling for geomorphological ranking. Furthermore, we propose strategic solutions to provide mitigation and protection from negative impacts with the aim of improving the level of awareness of flood geomorphology. The hazard model of geomorphological ranking was used in mapping and calculating the degree of hazards using 24 geomorphometric criteria. These criteria were divided into formal criteria, terrain criteria, and criteria related to the drainage network. The results of the study revealed that the drainage sub-basins are exposed to flood hazards along the Al-Shamal train pathway in the city of Qurayyat. The very high flood hazard constituted $4228.3 \mathrm{~km}^{2}$, accounting for $70.3 \%$ and $65.7 \%$, respectively, of the drainage basins of the wadis of Makhrouq and Bayer. The high flood hazard represented $61 \%\left(4712.4 \mathrm{~km}^{2}\right)$ of the basin of the wadis of Sarmadaa. The medium flood hazard was concentrated in the drainage basin of the wadi of Hasidah, accounting for nearly $57.7 \%$ $\left(1271.3 \mathrm{~km}^{2}\right)$. The very low flood hazard was present in $46.5 \%$ of the drainage basin of the wadis of Hasidah Umm Nakhla, accounting for an area of $799.4 \mathrm{~km}^{2}$. The methodology applied in this study can be used in the estimation of flood hazards in different drainage basins throughout Saudi Arabia and in similar arid regions.
\end{abstract}

Keywords: GIS; drainage basins; flood geomorphology; hazard model for geomorphological ranking; Al-Shamal train pathway; flood hazard maps 


\section{Introduction}

Flash flooding is considered one of the most severe weather-related natural disasters. The hazards of flash flooding occur due to its sudden and unexpected occurrence. Flooding is expected to be more severe, frequent, and destructive in the coming years because of climate change and urban expansion, which increases runoff [1-4].

Flood disasters that occur in dry environments have several challenges relating to the unique characteristics of runoff systems in these environments. In addition, there is a lack of full understanding of the geomorphological characteristics of the drainage basins and their associated processes [5].

The extraction of geomorphological features using geographic information systems (GIS) techniques is a vital aspect of flood hazard mapping. The revolution in GIS software development and open-source datasets has attracted the interest of researchers to implement new automated algorithms to study morphometry, topography, surface, and flood hazard modeling [6-8].

In recent years, flood mapping has become a key input into flood mitigation. The flood hazard mapping process aims to provide residents with information about the proposed damage and relevant potential prevention measures [6]. Flood maps are nonstructural representations used to reduce flood damage, and are produced for multiple purposes, such as flood tracking, emergency action planning, flood information, and flood hazard reduction solutions [9].

In recent decades, several methods have been developed for the mapping of flood hazard, including the geomorphological ranking method. In this method, five classes are created for each geomorphometric criterion and ranks are then assigned to each class according to the extent of its impact on the occurrence of flood. From the first to the fifth, these ranks represent the very low, low, medium, high, and very high hazard, respectively. The ranks of each basin are grouped according to the sum of the ranks of all basin geomorphometric criteria to produce the geomorphometric number of the basin. The higher the morphometric number of the basin, the higher the basin's hazards. Several studies have used the geomorphological ranking method to determine the drainage basins exposed to flood hazards [10-18].

GIS-based Multicriteria Decision Analysis (GIS-MCDA) is the most common criterion method for mapping flood hazards. Multicriteria analysis is an important tool for analyzing complex decision issues, which often involve incomparable criteria or data [19]. The analytic hierarchical process method (AHP) is the most used method for multicriteria decision making [20]. AHP is suitable for modeling flood hazards in urban areas, which depends on identifying the criteria that influence hazard levels, where weights of the criteria are determined using AHP.

A number of studies have used the multicriteria analysis method [21-30]. Hydraulic modeling using the HEC-RAS program is one of the most important methods used to model flood hazards in urban areas because it provides one- and two-dimensional models for the spread, depth, and speed of floodwater $[6,9,31-39]$.

References [40-46] applied a degree of flood hazard model. This model is based on calculating the degree of hazard for each geomorphometric criterion for the drainage sub-basins using mathematical equations, and then calculating the degree of hazards for each drainage sub-basin.

The area investigated in the current study is exposed to flood hazards from five wadis flowing from west to east, namely: (1) Wadi of Makhrouq, which affects Haditha village and the railway in the north of Qurayyat city. (2) Wadi Hasidah Algharbya, which impacts the north of the city of Qurayyat. (3) Wadi of Hasidah Umm Nakhla, which impacts the southern region of Qurayyat city. (4) Wadi of Bayer, which influences the villages of Bayer and Ghati and the adjacent railway. (5) Wadi of Sarmadaa, which impacts the villages of Nassifah, Gamagem, and Rudaifaah. The flows of these wadis have major negative impacts due to the occurrence of annual frequent flooding.

Flooding that occurred on 10 November 2018 was severe and completely halted traffic; submerged homes and schools, Qurayyat hospital, and the villages of Ghati, Bayer, and Haditha; displaced residents of the affected areas; and partially destroyed railways. Furthermore, the construction of the Al-Shamal train pathway in 2017, and its crossings near the villages and cities of Qurayyat, has led 
to the changes in land use and the morphology of the wadis, thereby increasing the flood hazard in the region.

Destructive flooding occurs frequently in the urban area of Qurayyat City. Increased urbanization and rapid population growth have worsened the impacts of these events. Consequently, flooding constitutes a hazard in urban areas. Flood hazard studies are required in urban areas, particularly due to uncontrolled and ad hoc building construction, and lack of urban planning [47,48].

This study is unique due to the scarcity of existing research that addresses flood hazards in the drainage basins of the northern region of the Kingdom of Saudi Arabia (KSA). The study aims to determine the damage caused by flooding in the city of Qurayyat and the pathway of the Al-Shamal railway. Railways in Saudi Arabia have strategic, economic, and developmental importance. Furthermore, they are subject to potential damage due to geomorphological, hydrological, and flood hazards because of the nature of the climate and the topography of the area in which they are located. Only two previous studies have examined the railways in Saudi Arabia. The first examined the impacts of land use changes and their role in increasing flood hazards of the Riyadh-Dammam train in the eastern region from 2011 to 2017 [9]. The second study examined a small part of the Al-Shamal train line at the beginning of its pathway in the city of Riyadh and focused on the impacts of morphological characteristics [49].

The main objective of this study is to map the flood hazards along the Al-Shamal train line in the city of Qurayyat, Saudi Arabia, using GIS and the geomorphological ranking method. The study applied the Geomorphometric-Hazard Model to calculate the degree of hazards using 24 geomorphologic criteria for the drainage sub-basins. The selected criteria were categorized into three groups, namely, form criteria, terrain criteria, and criteria related to the water drainage network. Moreover, the study addressed mitigation and adaptation measures for flood hazards for future planning decisions in the study area.

\section{Study Area}

The administrative location of the study area is in the north of the Jawf region in the north of Saudi Arabia. The main drainage basins that affect the city of Qurayyat and the Al-Shamal train line adjacent to it lie on the international border between Saudi Arabia and Jordan. The city of Qurayyat is located about $1200 \mathrm{~km}$ from Riyadh (the capital of Saudi Arabia), about $310 \mathrm{~km}$ from Sakaka, and about $350 \mathrm{~km}$ from the city of Arar. It is bordered to the north and west by Jordan, to the east by Turaif governorate, and to the south, Jawf region. Figure 1 shows the study area.

The study area is a drainage environment for the drainage basins located in the southeast of Jordan. The drainage basins in the study area, from north to south, are Makhrouq, Hasidah Algharbya, Hasidah Umm Nakhla, Bayer, and Sarmadaa. The drainage basins influencing the city of Qurayyat and the Al-Shamal train pathway are located between the latitudes of $3^{\circ} 16^{\prime} 9.75^{\prime \prime}$ to $31^{\circ} 31^{\prime} 33.01^{\prime \prime}$ north and the longitudes of $36^{\circ} 30^{\prime} 45.71^{\prime \prime}$ to $37^{\circ} 48^{\prime} 52.1^{\prime \prime}$ east. The total area of the drainage basins is about $11,011.47 \mathrm{~km}^{2}$. Of this total, $1974.87 \mathrm{~km}^{2}(17.93 \%)$ is located in Saudi Arabia and $9036.6 \mathrm{~km}^{2}(82.07 \%)$ in Jordan. Figure 2 shows the digital elevation model (DEM) of the study area in 2020. 




Figure 1. Map of the study area in Saudi Arabia. 




Figure 2. Digital elevation model (DEM, $12.5 \mathrm{~m}$ ) of the study area in 2020.

\section{Methodology}

The geomorphological ranking model is considered one of the most important scientific methods used to map flood hazards of the drainage basins. The model calculates the degree of hazard for each geomorphometric criterion in each sub-basin, and then calculates the degree of hazard for each subdrain basin.

The integration in this paper used GIS coupled with geomorphometric parameters to study the flood hazards in the drainage basins of the study area. GIS is used as a tool to visualize input and output data, in addition to calculating the spatial information of model results [50,51].

Figure 3 illustrates the methodology applied in this paper. Both GIS and the Watershed Modeling System (WMS) were used to achieve the objectives of this research, which can be summarized as:

1. Study the flood hazards of the drainage basins in the study area along the Al-Shamal train line using GIS.

2. Develop a flood model based on 24 geomorphometric parameters.

3. Suggest strategic solutions for mitigation for and protection from the negative impacts of floods along the Al-Shamal train line. 


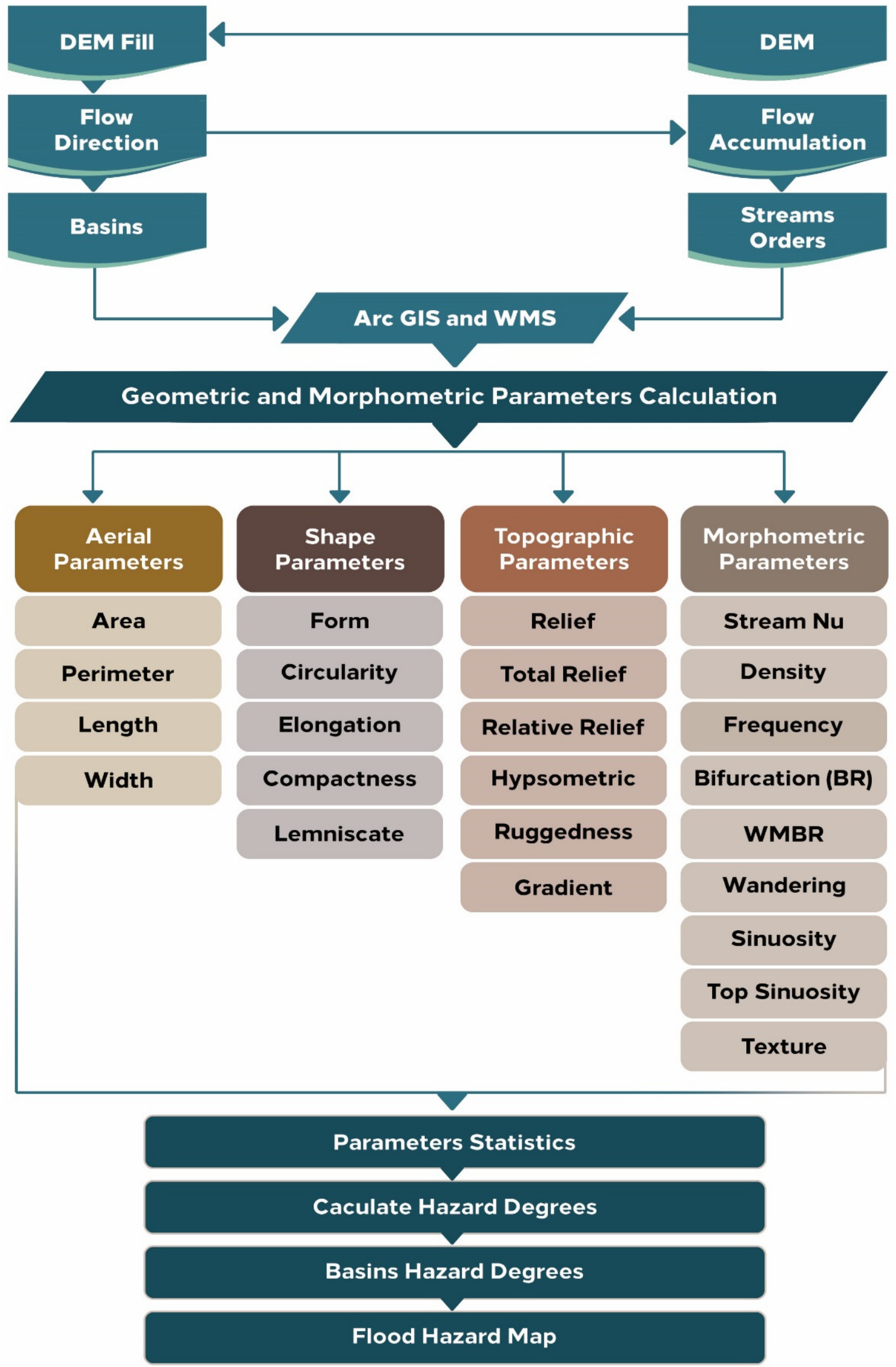

Figure 3. Methodology flowchart. 
The first step of the methodology was to enter the downloaded DEM into ArcGIS to perform hydrological analysis and obtain the following layers:

1. Fill.

2. Flow direction and basins.

3. Flow accumulation and stream order.

As a subsequent step, all previous layers were entered into the WMS to obtain:

1. Aerial parameters.

2. Shape parameters.

3. Topographic parameters.

4. Morphometric parameters.

\subsection{Data Collection}

Multiple data types and sources were collected to assess the potential flood hazards on the Al-Shamal train line based on the geomorphometric characteristics of the drainage basins affecting the study area. All data layers were standardized for integration into the GIS environment. Table 1 shows the data collected for the study, their relevant characteristics, including spatial accuracy or scale, and source or website used to download the data.

Table 1. Description of the data used in the study.

\begin{tabular}{|c|c|c|c|}
\hline \multirow[b]{2}{*}{ Criterion } & \multicolumn{2}{|l|}{ Data Used to Extract Criteria } & \multirow{2}{*}{$\begin{array}{c}\text { Authority/Website Used to Obtain } \\
\text { the Data }\end{array}$} \\
\hline & Data Type & $\begin{array}{l}\text { Scale/Spatial } \\
\text { Resolution }\end{array}$ & \\
\hline Slope & DEM & $12.5 \mathrm{~m}$ & http://vertex-retired.daac.asf.alaska.edu \\
\hline Land Cover & Landsat 8 OLI/TIRS & $30 \mathrm{~m}$ & http://earthexplorer.usgs.gov \\
\hline Drainage Density & The wadis network derived from the DEM & $12.5 \mathrm{~m}$ & http://vertex-retired.daac.asf.alaska.edu \\
\hline Geological Formation & Geological maps & 1: 250,000 & Saudi Geological Survey Authority \\
\hline
\end{tabular}

The collected data included a digital elevation model (DEM), topographic maps, and satellite images. A digital elevation model (DEM) with a spatial resolution of $12.5 \mathrm{~m}$ was downloaded from http://vertex-retired.daac.asf.alaska.edu. Topographic and geological maps with drawing scales of 1:50,000 and 1:250,000, respectively, were obtained from the Saudi Geological Survey (SGS). Land cover was derived from Landsat-8 OLI/TIRS satellite images with a spatial resolution of $30 \mathrm{~m}$, downloaded from http://earthexplorer.usgs.gov. Drainage basins were created from a network of wadis derived from the DEM and topographic maps. Figures 4 and 5 show the land cover and the drainage basins of the study area. 


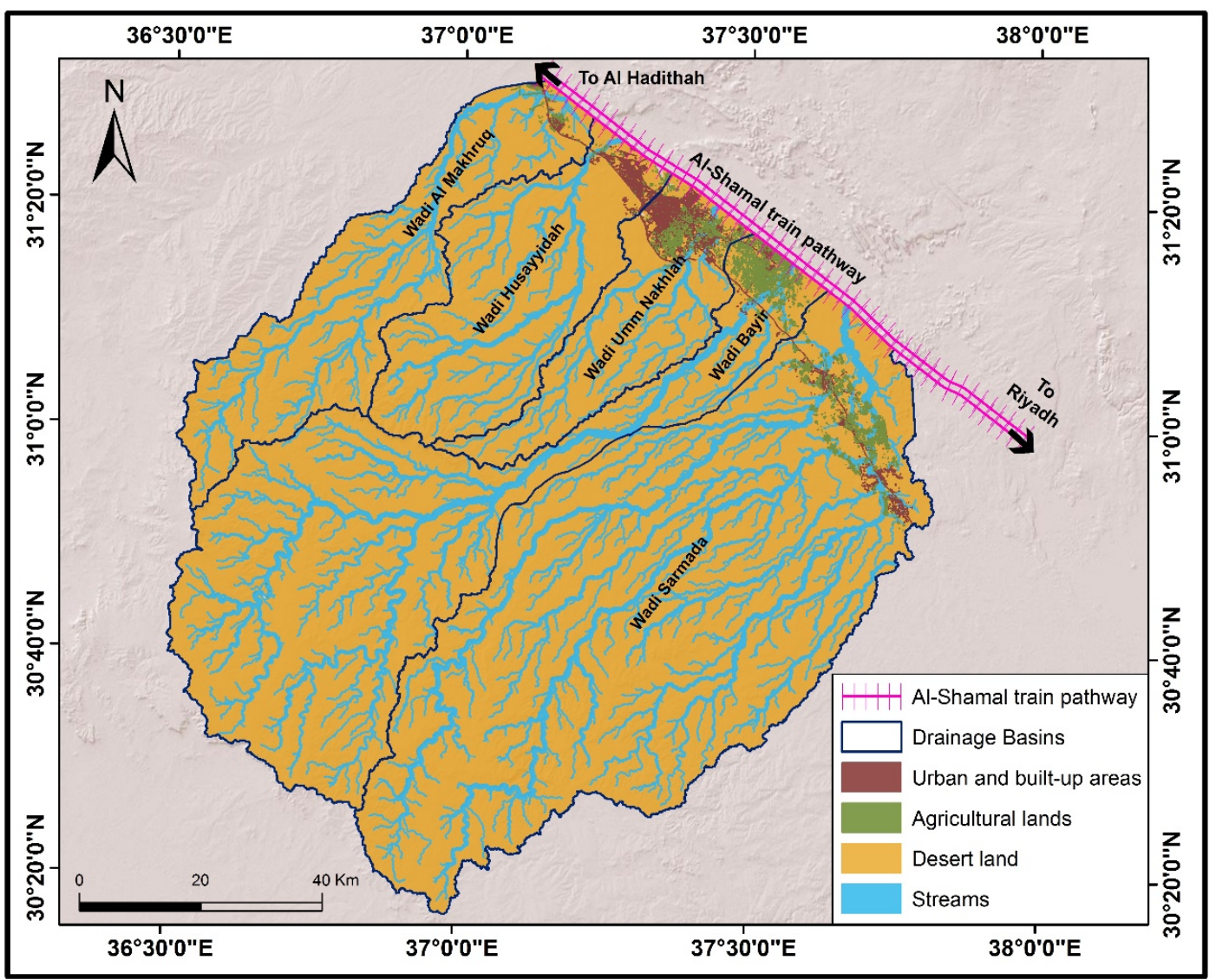

Figure 4. Land use of the study area in 2020.

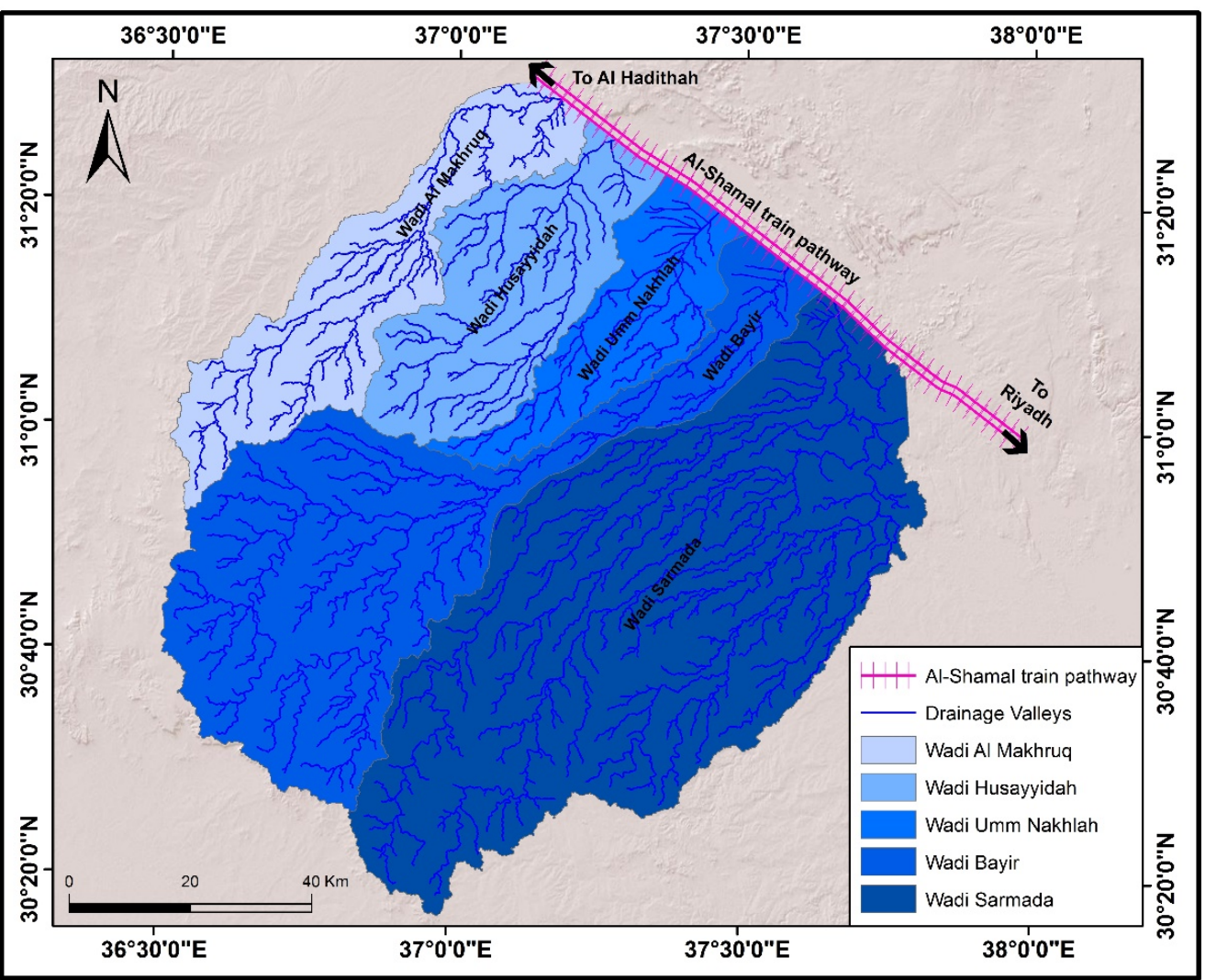

Figure 5. Drainage basins of the study area in 2020. 


\subsection{Extraction of the Geomorphometric Criteria}

The collected data were used to extract various geomorphometric parameters using hydrological analysis. The geomorphometric criteria parameters included: (1) the wadis, which were derived from the downloaded DEM; (2) land cover, which was extracted from the downloaded Landsat satellite images; (3) the stream order and drainage density, which were derived from the network-based wadis, in turn, on the downloaded DEM; (4) and rock types, which were digitized from the geological map. Twenty-four geomorphometric parameters were identified according to their direct relationship to flood hazards. The value of the criterion for each drainage basin affecting the Al-Shamal train line was calculated using the geomorphometric mathematical equations, GIS software, and the Watershed Modeling System (WMS). Table 2 illustrates the geomorphometric criteria used in the study.

Table 2. The geomorphometric criteria used to identify drainage basins exposed to flood hazards.

\begin{tabular}{|c|c|c|c|c|}
\hline$\#$ & Criterion & $\begin{array}{c}\text { Symbolic } \\
\text { Parameter }\end{array}$ & Equation/Software & Reference \\
\hline 1 & The area of the basin & A & WMS & [52] \\
\hline 2 & Basins length & $\mathrm{L}_{\mathrm{b}}$ & WMS & [53] \\
\hline 3 & Stream order & $\mathrm{u}$ & ArcGIS & [54] \\
\hline 4 & Total basin relief & $\mathrm{H}$ & $\mathrm{H}(\mathrm{m})=\mathrm{Z}(\mathrm{m})-\mathrm{z}(\mathrm{m})$ & [54] \\
\hline 5 & Relief ratio & $\mathrm{R}_{\mathrm{r}}$ & $\mathrm{R}_{\mathrm{r}}=\mathrm{H} / \mathrm{L}$ & [53] \\
\hline 6 & Relative relief & $\operatorname{ReRe}$ & $\operatorname{Re} \operatorname{Re}=\mathrm{H} / \mathrm{P}$ & [53] \\
\hline 7 & Ruggedness number & $\mathrm{R}_{\mathrm{n}}$ & $R_{n}=(D \times R h) / 1000$ & [54] \\
\hline 8 & Gradient ratio & $\mathrm{R}_{\mathrm{g}}$ & $\mathrm{R}_{\mathrm{g}}=(\mathrm{Z}-\mathrm{z}) / \mathrm{L}_{\mathrm{b}}$ & [55] \\
\hline 9 & Stream frequency & $\mathrm{F}$ & $\mathrm{F}=\sum \mathrm{Nu} / \mathrm{A}$ & [52] \\
\hline 10 & Drainage density & $\mathrm{D}$ & $\mathrm{D}=\bar{\sum} \mathrm{LU} / \mathrm{A}$ & [56] \\
\hline 11 & Bifurcation ratio & $\mathrm{R}_{\mathrm{b}}$ & $\mathrm{R}_{\mathrm{b}}=\mathrm{Nu} / \mathrm{Nu}+1$ & [52] \\
\hline 12 & Weighted mean bifurcation ratio & $\mathrm{WMRb}$ & $\mathrm{WMRb}=\sum(\mathrm{Rbu} / \mathrm{Rbu}+1) /(\mathrm{Nu}+\mathrm{Nu}+1) / \sum \mathrm{N}$ & [54] \\
\hline 13 & Circularity ratio & $\mathrm{R}_{\mathrm{c}}$ & $R_{c}=12.57 \mathrm{~A} / \mathrm{P} 2$ & [53] \\
\hline 14 & Elongation ratio & $\mathrm{R}_{\mathrm{e}}$ & $\sqrt[2]{(A / \pi)} / L$ & [53] \\
\hline 15 & Relative perimeter & $\mathrm{P}_{\mathrm{r}}$ & $\operatorname{Pr}=\mathrm{A} / \mathrm{P}$ & [53] \\
\hline 16 & Mean basin width & $\mathrm{W}_{\mathrm{b}}$ & $\mathrm{W}_{\mathrm{b}}=\mathrm{A} / \mathrm{L}$ & [56] \\
\hline 17 & Form factor ratio & $F_{f}$ & $F_{f}=A / L_{b}^{2}$ & [56] \\
\hline 18 & Compactness coefficient & $\mathrm{C}_{\mathrm{c}}$ & $C_{C}=0.2841 \mathrm{P} / A^{0.5}$ & [52] \\
\hline 19 & Lemniscate factor & K & $\mathrm{K}=1.000 L_{b}^{2} / 4 A$ & [57] \\
\hline 20 & Wandering ratio & $\mathrm{R}_{\mathrm{W}}$ & $\mathrm{R}_{\mathrm{W}}=\mathrm{C} / \mathrm{L}$ & [58] \\
\hline 21 & Hypsometric integral & $\mathrm{H}$ & $H=\left(Z^{\prime}-Z o\right) /(Z \max -Z o)$ & [59] \\
\hline 22 & Texture ratio & $\mathrm{I}$ & $\mathrm{I}=\mathrm{u} / \mathrm{P}$ & [52] \\
\hline 23 & Sinuosity index & $\mathrm{S}_{\mathrm{i}}$ & $\mathrm{S}_{\mathrm{I}}=\mathrm{C} 1 / \mathrm{V} 1$ & {$[60]$} \\
\hline 24 & Topographic sinuosity index & Tsi & $\mathrm{Tsi}=\mathrm{V} 1-1 / \mathrm{C} 1-1 \times 100$ & {$[60]$} \\
\hline
\end{tabular}

\subsection{The Ranks of the Geomorphometric Criteria Layer}

The rank of each criterion was determined for each drainage basin in the study area. Geomorphometric criteria were used that increased with the increase of the rank of the hazard, such as the area, basin length, number of streams, circularity ratio, stream frequency, and drainage density. Other geomorphometric criteria increased with the decrease of the rank of the hazard, such as the elongation ratio, compactness coefficient, bifurcation ratio, wandering ratio, and hypsometric integral. The criteria are shown in Table 3. 
Table 3. Ranks for geomorphometric criteria of the drainage sub-basins affecting the Al-Shamal train line.

\begin{tabular}{|c|c|c|c|c|c|c|}
\hline$\#$ & Criterion & Bayer & Makhrouq & $\begin{array}{l}\text { Hasidah } \\
\text { Algharbya }\end{array}$ & $\begin{array}{c}\text { Hasidah } \\
\text { Umm Nakhla }\end{array}$ & Sarmadaa \\
\hline 1 & The area of the basin & 3 & 1 & 1 & 1 & 5 \\
\hline 2 & Basins length & 5 & 3 & 1 & 1 & 5 \\
\hline 3 & Stream order & 3 & 1 & 1 & 1 & 5 \\
\hline 4 & Total basin relief & 5 & 5 & 1 & 1 & 4 \\
\hline 5 & Relief ratio & 1 & 4 & 5 & 4 & 1 \\
\hline 6 & Relative relief & 2 & 5 & 3 & 3 & 1 \\
\hline 7 & Ruggedness number & 5 & 5 & 1 & 2 & 3 \\
\hline 8 & Gradient ratio & 1 & 4 & 5 & 4 & 1 \\
\hline 9 & Stream frequency & 5 & 5 & 4 & 1 & 4 \\
\hline 10 & Drainage density & 4 & 5 & 2 & 1 & 2 \\
\hline 11 & Bifurcation ratio & 5 & 5 & 5 & 1 & 5 \\
\hline 12 & Weighted mean bifurcation ratio & 5 & 5 & 5 & 1 & 5 \\
\hline 13 & Circularity ratio & 1 & 1 & 5 & 2 & 5 \\
\hline 14 & Elongation ratio & 5 & 5 & 1 & 3 & 1 \\
\hline 15 & Relative perimeter & 3 & 1 & 2 & 1 & 5 \\
\hline 16 & Mean basin width & 3 & 1 & 2 & 1 & 5 \\
\hline 17 & Form factor ratio & 5 & 5 & 1 & 4 & 1 \\
\hline 18 & Compactness coefficient & 1 & 1 & 5 & 3 & 5 \\
\hline 19 & Lemniscate factor & 4 & 5 & 1 & 3 & 1 \\
\hline 20 & Wandering ratio & 3 & 4 & 4 & 5 & 1 \\
\hline 21 & Hypsometric integral & 1 & 1 & 1 & 1 & 1 \\
\hline 22 & Texture ratio & 3 & 5 & 4 & 5 & 1 \\
\hline 23 & Sinuosity index & 2 & 4 & 4 & 5 & 1 \\
\hline \multirow[t]{2}{*}{24} & Topographic sinuosity index & 4 & 3 & 4 & 1 & 5 \\
\hline & Total & 79 & 84 & 68 & 55 & 73 \\
\hline
\end{tabular}

\subsection{The Degree of the Geomorphometric Hazards in the Sub-Basins}

The degree of the hazards of the geomorphometric criteria in each drainage sub-basin ranged between one (the lowest hazard value) and five (the largest hazard value). The following equations were used to calculate the degree of the hazards of the geomorphometric criteria:

$$
\text { Hazard Degree }=\frac{4(X-X \min )}{(X \max -X \min )}+1
$$

where:

$\mathrm{X}$ : value of the geomorphometric criterion within a sub-basin;

$X$ min: lowest value for the geomorphometric criterion in all drainage sub-basins;

Xmax: largest value for the geomorphometric criterion in all drainage sub-basins;

1 and 4: fixed numbers.

Equation (1) is used to calculate the degree of the hazard of the geomorphometric criteria that have a direct impact on the degree of flood hazard in which the value of each geomorphometric criterion increases as the degree of flood hazard increases, and vice versa.

$$
\text { Hazard Degree }=\frac{4(X-X \max )}{(X \min -X \max )}+1
$$

Equation (2) is used to calculate the degree of the hazard for the geomorphometric criteria that have an indirect impact on the degree of flood hazard in which the value of each geomorphometric criterion increases as the degree of the flood hazard decreases, and vice versa. The criteria with a direct impact on the degree of flood hazard are area, relief ratio, slope, discharge density, and stream frequency, whereas the criteria that have an indirect impact on the degree of flood hazard are the hypsometric integral, elongation ratio, form factor, compactness coefficient, bifurcation ratio, and the wandering ratio. Table 4 shows the hazard degree values for the geomorphometric criteria for all sub-basins. 
Table 4. The hazard values of the geomorphometric criteria for the drainage sub-basins.

\begin{tabular}{|c|c|c|c|c|c|c|}
\hline$\#$ & Criterion & Bayer & Makhrouq & $\begin{array}{c}\text { Hasidah } \\
\text { Algharbya }\end{array}$ & $\begin{array}{c}\text { Hasidah } \\
\text { Umm Nakhla }\end{array}$ & Sarmadaa \\
\hline 1 & The area of the basin & 3.15 & 1.54 & 1.48 & 1 & 5 \\
\hline 2 & Basins length & 5 & 2.95 & 1.02 & 1 & 4.85 \\
\hline 3 & Stream order & 3.24 & 1.62 & 1.52 & 1 & 5 \\
\hline 4 & Total basin relief & 5 & 4.6 & 1.75 & 1 & 3.95 \\
\hline 5 & Relief ratio & 1.64 & 4.08 & 5 & 3.95 & 1 \\
\hline 6 & Relative relief & 2.33 & 5 & 3.33 & 3.33 & 1 \\
\hline 7 & Ruggedness number & 4.22 & 5 & 1 & 1.89 & 3.22 \\
\hline 8 & Gradient ratio & 1.73 & 4.09 & 5 & 3.91 & 1 \\
\hline 9 & Stream frequency & 5 & 4.85 & 3.42 & 1 & 4.1 \\
\hline 10 & Drainage density & 4 & 5 & 2 & 1 & 2 \\
\hline 11 & Bifurcation ratio & 4.99 & 5 & 5 & 1 & 4.74 \\
\hline 12 & Weighted mean bifurcation ratio & 4.96 & 5 & 4.91 & 1 & 4.96 \\
\hline 13 & Circularity ratio & 1.36 & 1 & 4.64 & 2.45 & 5 \\
\hline 14 & Elongation ratio & 4.2 & 5 & 1 & 3.4 & 1 \\
\hline 15 & Relative perimeter & 2.63 & 1.25 & 2 & 1 & 5 \\
\hline 16 & Mean basin width & 2.62 & 1.23 & 2.17 & 1 & 5 \\
\hline 17 & Form factor ratio & 4.29 & 5 & 1 & 3.82 & 1.24 \\
\hline 18 & Compactness coefficient & 1.67 & 1 & 5 & 3 & 5 \\
\hline 19 & Lemniscate factor & 3.68 & 5 & 1 & 3.07 & 1.14 \\
\hline 20 & Wandering ratio & 2.6 & 4.2 & 4.2 & 5 & 1 \\
\hline 21 & Hypsometric integral & 1 & 1 & 1 & 1 & 1 \\
\hline 22 & Texture ratio & 3.23 & 4.54 & 3.97 & 5 & 1 \\
\hline 23 & Sinuosity index & 2.33 & 3.75 & 4.14 & 5 & 1 \\
\hline \multirow[t]{2}{*}{24} & Topographic sinuosity index & 3.99 & 2.66 & 3.63 & 1 & 5 \\
\hline & Total & 78.86 & 84.36 & 69.18 & 55.82 & 73.2 \\
\hline
\end{tabular}

\subsection{The Hazard Degree in the Sub-Basins}

In the final stage, the hazard degree in the drainage sub-basins was determined using three steps:

1. The hazards for all geomorphometric criteria were combined into one drainage sub-basin.

The hazard class width was calculated using Equation (3):

$$
\text { Hazard Class Width }=\frac{\sum \text { Nmax }-\sum \text { Nmin }}{n}
$$

where:

$\sum$ Nmax: largest total sum of the hazard values for one subdrain basin;

$\sum$ Nmin: lowest total sum of the hazard values for one subdrain basin;

$\mathrm{n}$ : number of hazard classes (very high, high, medium, low, and very low).

2. Determination of the hazard classes where:

- The first-class limit was the lowest total sum of the hazard values for one drainage sub-basin;

- The second-class limit was the sum of the lowest sum of the hazard values for one drainage sub-basin and the hazard class width.

This process was repeated to determine the other hazard classes. Finally, the severity degree of the subdrainage basin was determined using the total values of the degree of hazard in the basin of the five hazard classes. 


\section{Results and Discussions}

\subsection{Analysis of the Geomorphometric Characteristics of the Drainage Basins}

\subsubsection{General Geomorphological Appearance}

The most significant geomorphological characteristic of the study area was its intersection with five main wadis flowing from west to east. These wadis from north to south are as follows:

1. Wadi of Makhrouq, which affects the villages of Haditha to the north of the city of Qurayyat and intersects the railway in the north.

2. Wadi of Hasidah Algharbya, which affects the area to the north of the city of Qurayyat.

3. Wadi of Umm Nakhleh, which affects the southern region of the city of Qurayyat.

4. Wadi of Bayer, which affects the villages of Bayer and Ghati in addition to the adjacent railway.

5. Wadi of Sarmadaa, which affects the villages of Nassifah, Gamagem, and Rudaifaah.

These wadis originate in the western highlands of the mountains of Ragla Faras, Waqf Sawan, and Hadi. The total number of drainage basins was 146,640. The total length of the streams was $42,540.51 \mathrm{~km}$. The ranks of these streams ranged between the first and eighth as seen in Figure 6.

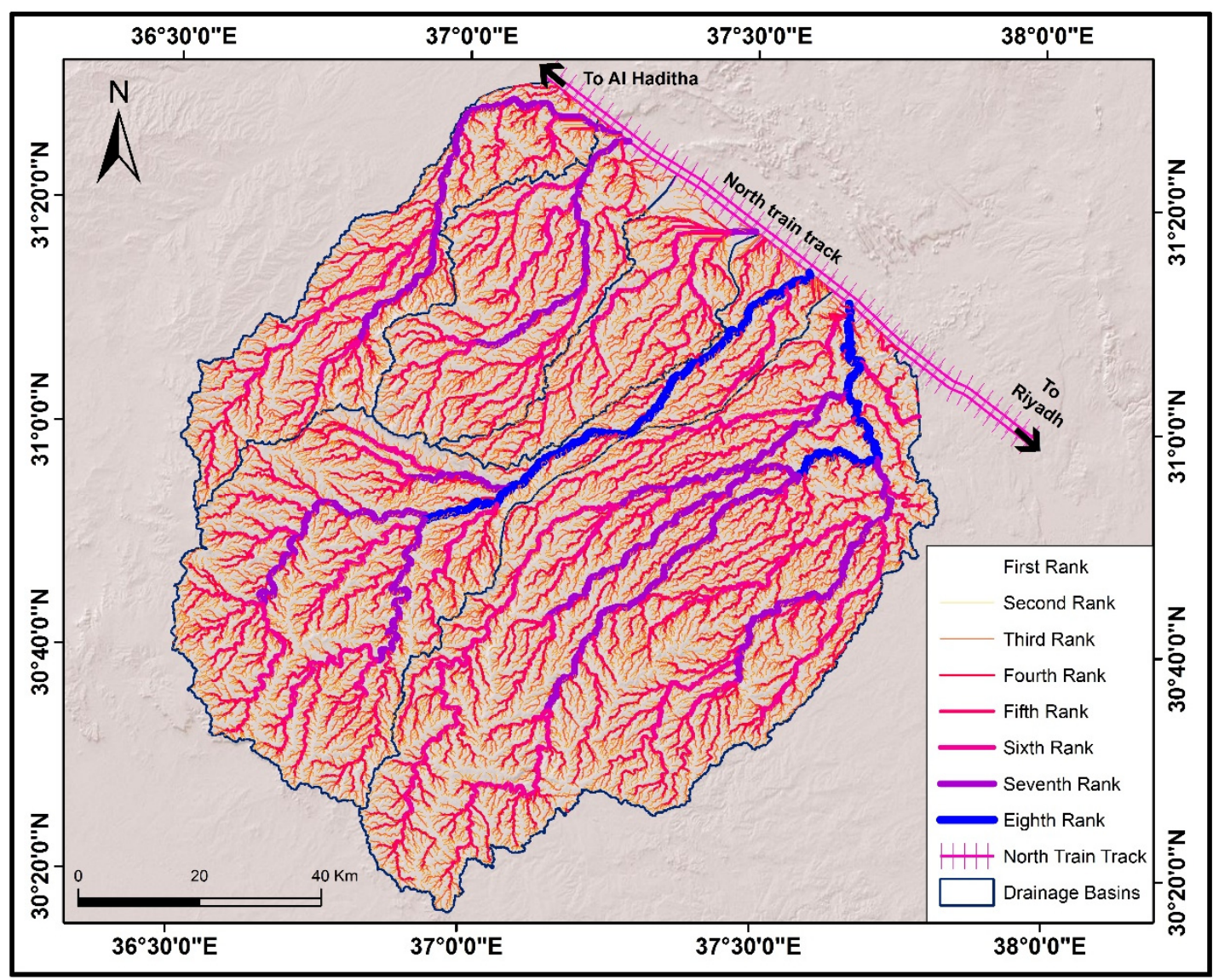

Figure 6. Ranks of the wadis in the study area in 2020.

\subsubsection{Geological Characteristics}

The study of geological formations is critical to assess flood hazards due to the relationship between natural and rocky features, of solid, soft, oblique, or horizontal types. The geological map of the study area is shown in Figure 7. The predominant rocks in the study area belong to the third and fourth geologic times. Sedimentary rocks exist in $99 \%$ of the area, while igneous rocks constitute only 
$1 \%$ in the southeast of the wadi Sarmadaa and consist of alkaline basalt resulting from lava flows and volcanic ash cones.



Figure 7. Geological formations in the study area in 2020.

Sedimentary rocks in the region belong to the formations of Sarhan and Rashrayan, which consist of limestone combined with dolomite, marl, chalk, and flintstone in separate areas of the study area. These rocks constitute about $53.6 \%$ of the area and are concentrated in the upper and middle regions of the basins of the study area. Flood sediments containing silt mixed with both sand and gravel occupy most of the flat and semiflat parts of the Hassida, Umm Nakhla, Bayer, and Sarmadaa basins, whose slopes are not more than $3^{\circ}$ and are traversed by the Al-Shamal train line. These sediments constitute nearly $12.8 \%$ of the area of the region and are concentrated in the mud and silt depressions in the lower part of the wadi of the Makhrouk basin. River sediments, wind sand sediments, and other sediments cover about $18.2 \%$ of the study area. Gravel sediments, which are spread over large areas of the central regions of the Hassida basins, Umm Nakhleh, Bayer, and Sarmadaa, and in limited areas of the wadi of Makhrouk, constitute $13.8 \%$ of the study area. Sand and phosphorous sediments, which consist of silica, occupy specific areas of the wadi of Sarmadaa and Bayer basins to a maximum of $0.3 \%$.

\subsubsection{Analysis of the Geomorphometric Characteristics}

The values of the different geomorphometric criteria for the drainage sub-basins were calculated using the WMS and ArcGIS software. Table 5 and Figures 8-13 present the values of the different geomorphometric criteria for the drainage sub-basins. 
Table 5. The values of the geomorphometric characteristics of the drainage basins affecting the Al-Shamal train line.

\begin{tabular}{|c|c|c|c|c|c|c|}
\hline$\#$ & Criterion & Bayer & Makhrouq & $\begin{array}{l}\text { Hasidah } \\
\text { Algharbya }\end{array}$ & $\begin{array}{c}\text { Hasidah } \\
\text { Umm Nakhla }\end{array}$ & Sarmadaa \\
\hline 1 & The area of the basin $\left(\mathrm{km}^{2}\right)$ & 2900.7 & 1327.6 & 1271.3 & 799.4 & 4712.4 \\
\hline 2 & Basins length $(\mathrm{km})$ & 124.33 & 92.42 & 62.32 & 62.02 & 122.07 \\
\hline 3 & Stream order & 39,491 & 18,004 & 16,631 & 9810 & 62,704 \\
\hline 4 & Total basin relief $(\mathrm{m})$ & 546 & 526 & 385 & 348 & 494 \\
\hline 5 & Relief ratio (m/km) & 4.39 & 5.69 & 6.18 & 5.62 & 4.05 \\
\hline 6 & Relative relief & 1 & 1.4 & 1.15 & 1.15 & 0.8 \\
\hline 7 & Ruggedness number & 2.04 & 2.11 & 1.75 & 1.83 & 1.95 \\
\hline 8 & Gradient ratio & 4.4 & 5.7 & 6.2 & 5.6 & 4 \\
\hline 9 & Stream frequency $\left(\right.$ stream $/ \mathrm{km}^{2}$ ) & 13.61 & 13.56 & 13.08 & 12.27 & 13.31 \\
\hline 10 & Drainage density $\left(\mathrm{km} / \mathrm{km}^{2}\right)$ & 3.9 & 3.93 & 3.84 & 3.81 & 3.84 \\
\hline 11 & Bifurcation ratio & 1.59 & 1.57 & 1.57 & 7.49 & 1.95 \\
\hline 12 & Weighted mean bifurcation ratio & 3.01 & 3 & 3.02 & 3.92 & 3.01 \\
\hline 13 & Circularity ratio & 0.16 & 0.15 & 0.25 & 0.19 & 0.26 \\
\hline 14 & Elongation ratio & 0.24 & 0.22 & 0.32 & 0.26 & 0.32 \\
\hline 15 & Relative perimeter $(\mathrm{km})$ & 6.1 & 3.9 & 5.1 & 3.5 & 9.9 \\
\hline 16 & Mean basin width $(\mathrm{km})$ & 23.3 & 14.4 & 20.4 & 12.9 & 38.6 \\
\hline 17 & Form factor ratio & 0.19 & 0.16 & 0.33 & 0.21 & 0.32 \\
\hline 18 & Compactness coefficient & 2.5 & 2.6 & 2 & 2.3 & 2 \\
\hline 19 & Lemniscate factor & 1.33 & 1.61 & 0.76 & 1.2 & 0.79 \\
\hline 20 & Wandering ratio & 1.5 & 1.3 & 1.3 & 1.2 & 1.7 \\
\hline 21 & Hypsometric Integral $\left(\mathrm{km}^{2} / \mathrm{m}\right)$ & 0.5 & 0.5 & 0.5 & 0.5 & 0.5 \\
\hline 22 & Texture ratio & 82.6 & 53.4 & 66.1 & 43.2 & 132.3 \\
\hline 23 & Sinuosity index & 1.52 & 1.34 & 1.29 & 1.18 & 1.69 \\
\hline 24 & Topographic sinuosity index & 65.61 & 74.17 & 67.95 & 84.86 & 59.12 \\
\hline
\end{tabular}

I. The Total Area of the Basin

The total area of the basin is an indication of the basin's dimensions and volume [54]. The total area of the basin is an important component for calculating many other geomorphometric parameters, such as drainage density, stream frequency, shape factor, elongation ratio, circularity ratio, and compactness coefficient [61]. The total area of the drainage sub-basins that affect the Al-Shamal train line is $799.4 \mathrm{~km}^{2}$ in the Umm Nakhleh Hasidah basin and $4712.4 \mathrm{~km}^{2}$ in the Sarmadaa basin.

\section{Basin Length}

The length of the basin determines the distance that the tributary network travels from the upper sources to the estuaries. It also indicates the formal parameters such as the shape of the basin, the form factor, and the elongation ratio. The length of the basin exceeds its width when the basin has the approximate shape of a rectangle and its elongation ratio increases, and vice versa [62,63]. The lengths of the drainage sub-basins affecting the Al-Shamal train line range from $62.02 \mathrm{~km}$ in the basin of Hasidah Umm Nakhleh to $124.33 \mathrm{~km}$ in the basin of Bayer.

\section{Number of Streams}

The number of tributaries in a drainage basin is an indicator of the severity of flooding in the basin. In addition, it is an indicator of other geomorphometric parameters, including the frequency of tributaries. A greater number of tributaries is a sign of high erosion rates and high drainage density with a lower bifurcation ratio [64]. The total number of streams of the drainage basins on the Al-Shamal train line ranges from 9810 streams in the basin of Hasidah Umm Nakhla and 62,704 streams in the basin of Sarmadaa. 


\section{Total Basin Relief}

Total basin relief is defined as the difference between the highest and lowest elevation of the basin. The value of the total basin relief is an indication of the relief, slope, and erosion rates [54,65]. Higher values of total basin relief indicate significant variation in basin depths, high slope, and increase in erosion rates. The total basin relief of the drainage sub-basins affecting the Al-Shamal train line ranges between $348 \mathrm{~m}$ in the basin of Hasidah Um Nakhla and $546 \mathrm{~m}$ in the basin of Bayer.

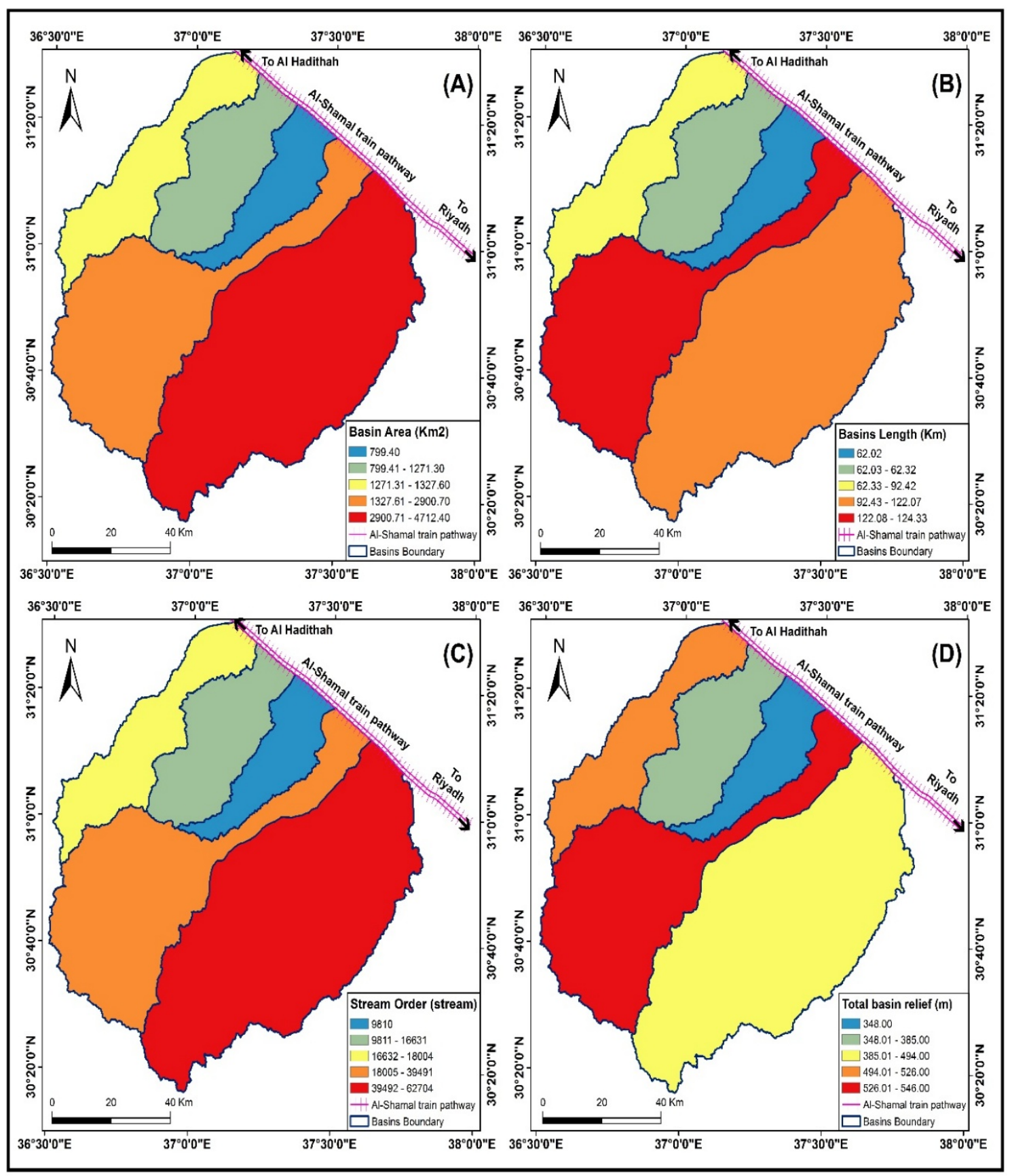

Figure 8. Geomorphometric criteria: (A) area; (B) basin length; (C) stream order; (D) total basin relief. 


\section{Relief Ratio}

The relief ratio is the ratio between the difference in the drainage basin and the length of the drainage basin. The relief ratio is an indication of relief, slope, and erosion rates [54,65]. A higher relief ratio indicates a large variation in basin depth, severe slope, and increasing erosion rates. The relief ratio of the drainage sub-basins affecting the Al-Shamal train pathway ranges between $4.05 \mathrm{~m} / \mathrm{km}$ in the basin of Sarmadaa and $6.18 \mathrm{~m} / \mathrm{km}$ in the basin of Hasidah Algharbya.

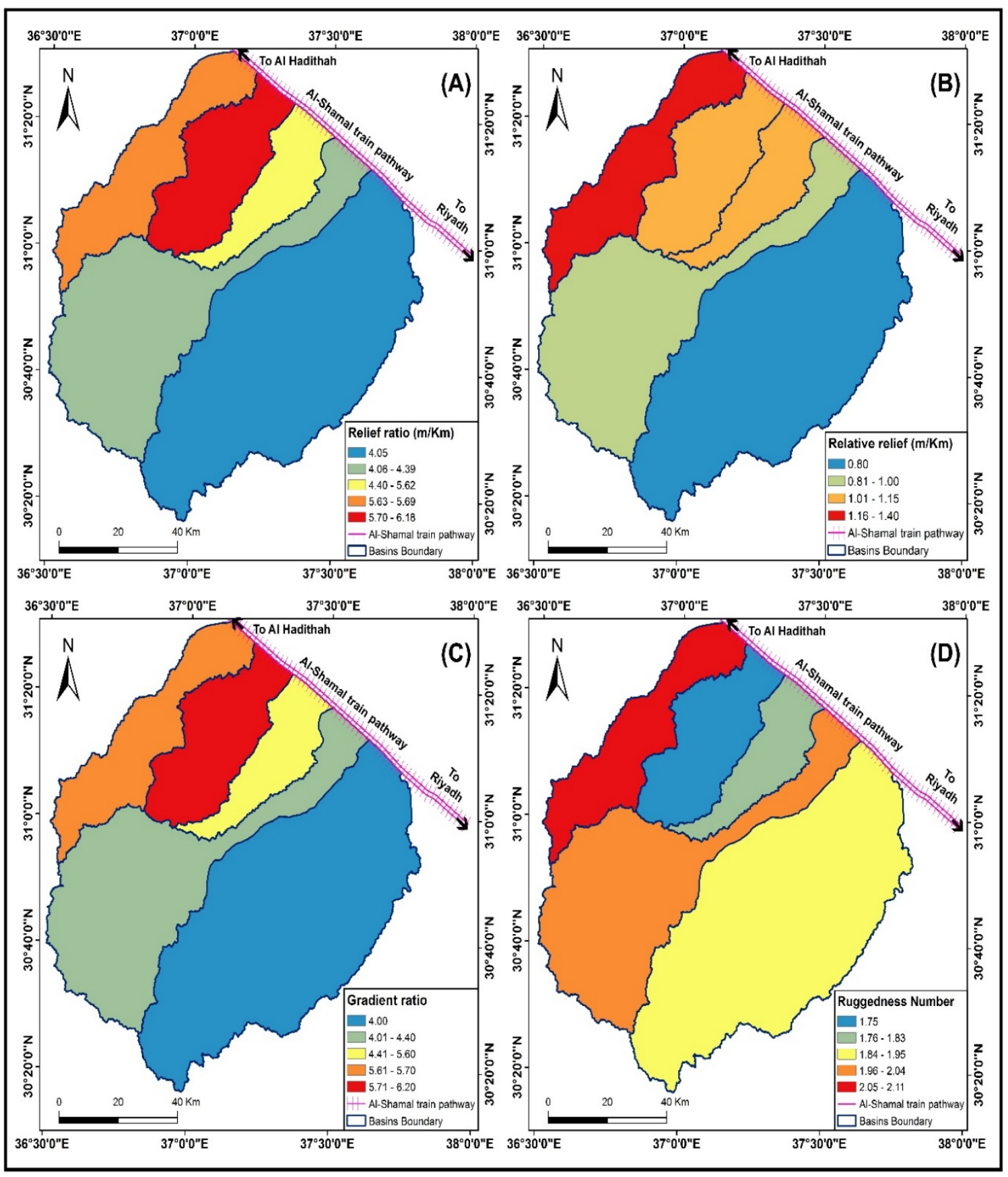

Figure 9. Geomorphometric criteria: (A) relief ratio; (B) relative relief; (C) ruggedness number; (D) gradient ratio. 


\section{Relative Relief}

Relative relief is defined as the ratio between the difference in the drainage basin and the circumference of the drainage basin. Relative relief indicates relief, slope, and erosion rates [54,65]. Higher values of relative relief indicate large differences in basin depths, severe slopes, and increased erosion rates. The relative relief values of the drainage basins on the Al-Shamal train line range between $0.8 \mathrm{~m} / \mathrm{km}$ in the basin of Sarmadaa, and $1.15 \mathrm{~m} / \mathrm{km}$ in the basins of Hasidah Algharbya and Hasidah Umm Nakhla.

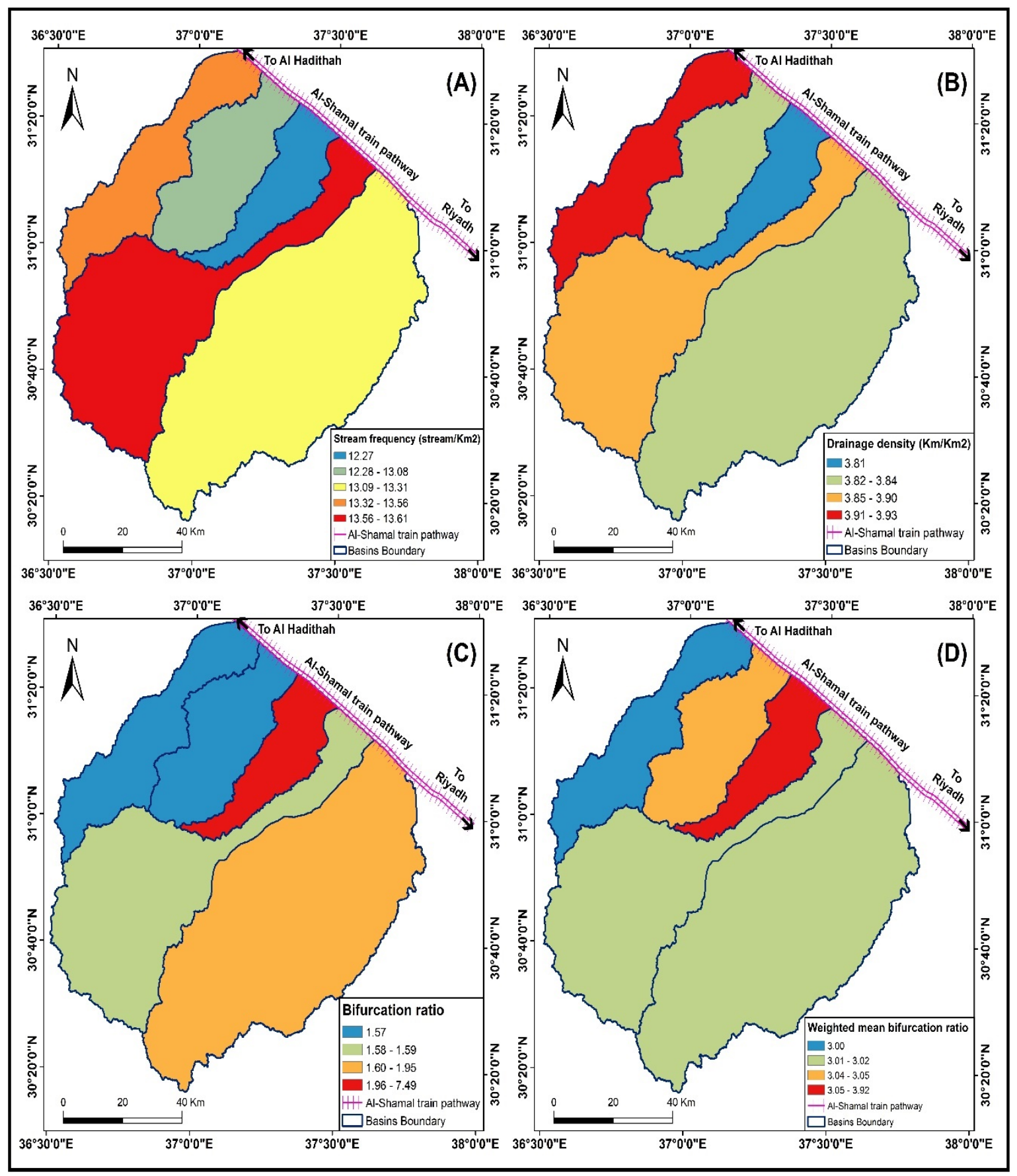

Figure 10. Geomorphometric criteria: (A) stream frequency; (B) drainage density; (C) bifurcation ratio; (D) weighted mean bifurcation ratio. 


\section{Ruggedness Number}

The ruggedness number is defined as the product of the drainage density and the difference in the depth of the drainage basin divided by a constant value. The ruggedness number is an indication of relief, drainage density, slope, soil erosion rates, and rock structure [62,63].

The ruggedness number is the product of the relief ratio and drainage density. Higher values of the ruggedness number indicate an increase in high relief ratio, an increase in the drainage density, heterogeneity in the geological structure, and high soil erosion rates. The values of the ruggedness number in the drainage sub-basins which affect the Al-Shamal train line range between 1.75 in the basin of Hasidah Algharbya and 2.11 in the basin of Makhrouq.

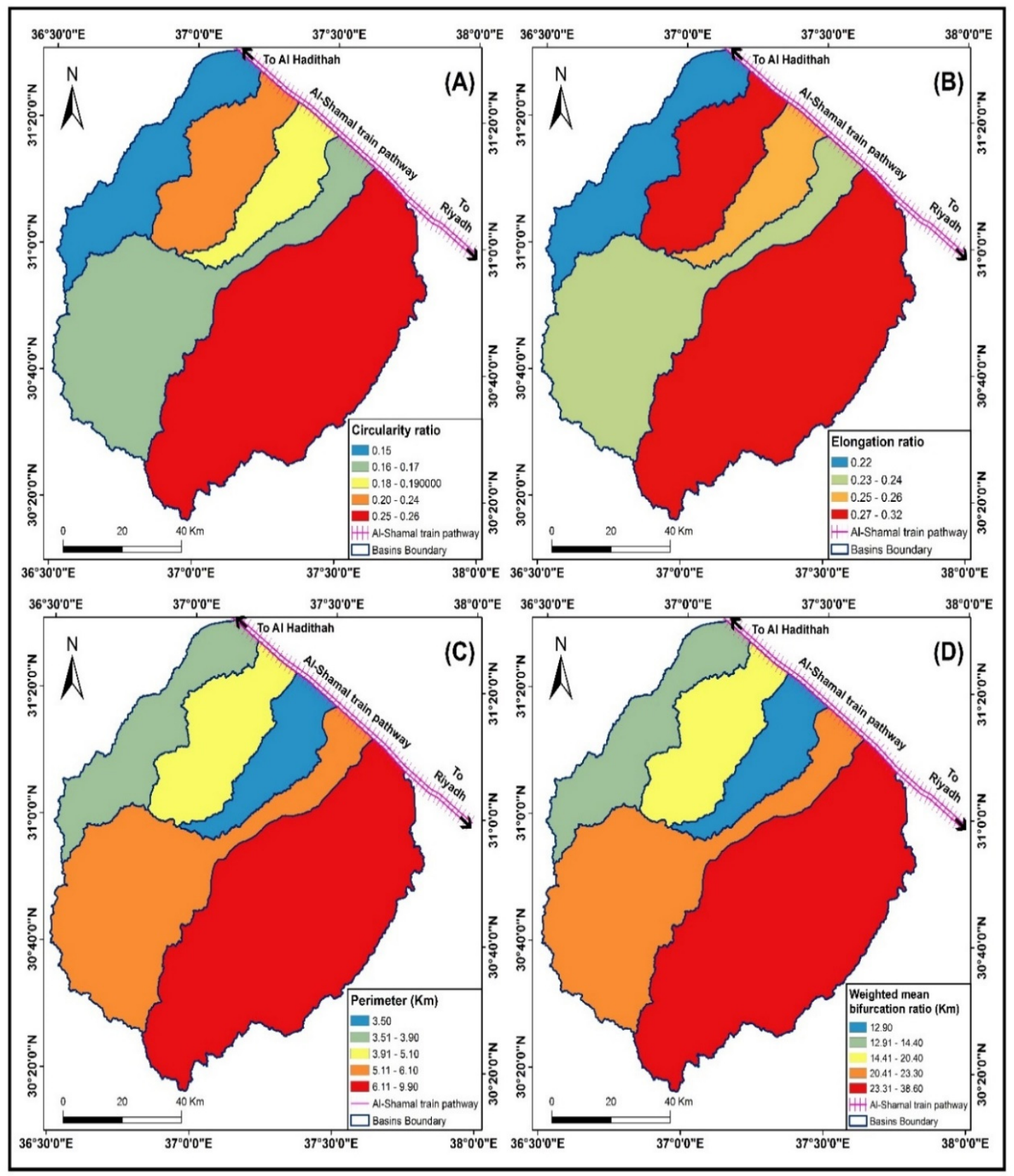

Figure 11. Geomorphometric criteria: (A) circularity ratio; (B) elongation ratio; (C) basin perimeter; (D) form factor. 


\section{Gradient Ratio}

The gradient ratio is defined as the ratio between the difference of the depths in the drainage basin and the length of the drainage basin [66]. The gradient ratio affects all geomorphometric characteristics of the water drainage properties, including the amount of surface runoff, intrusion rates, drainage intensity, flood severity, and erosion rates. The gradient ratios for drainage sub-basins affecting the Al-Shamal train pathway range from 4 in the basin of Sarmadaa to 6.2 in the basin of Hasidah Algharbya.

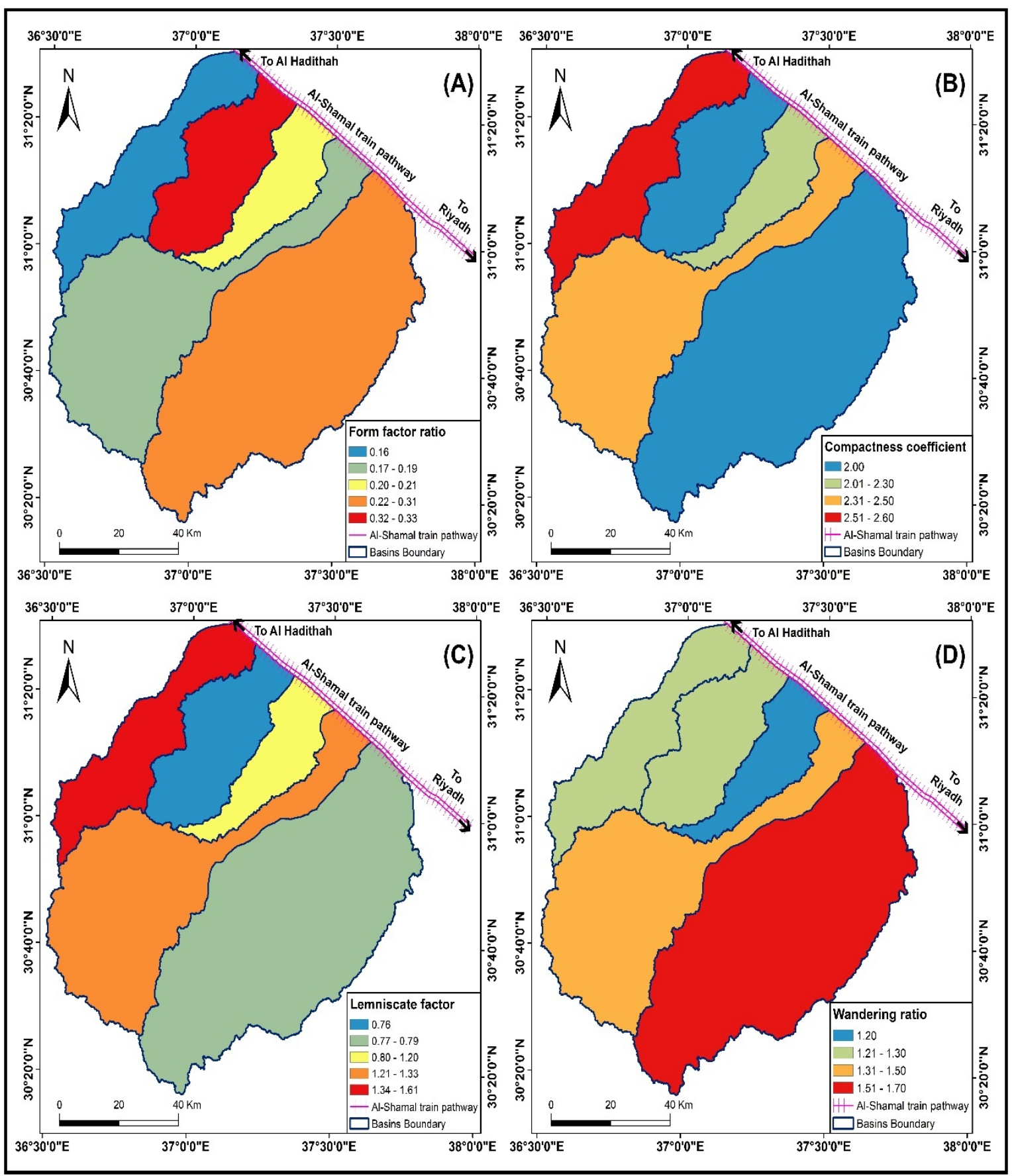

Figure 12. Geomorphometric criteria: (A) form factor; (B) compactness coefficient; (C) lemniscate factor; (D) wandering ratio. 


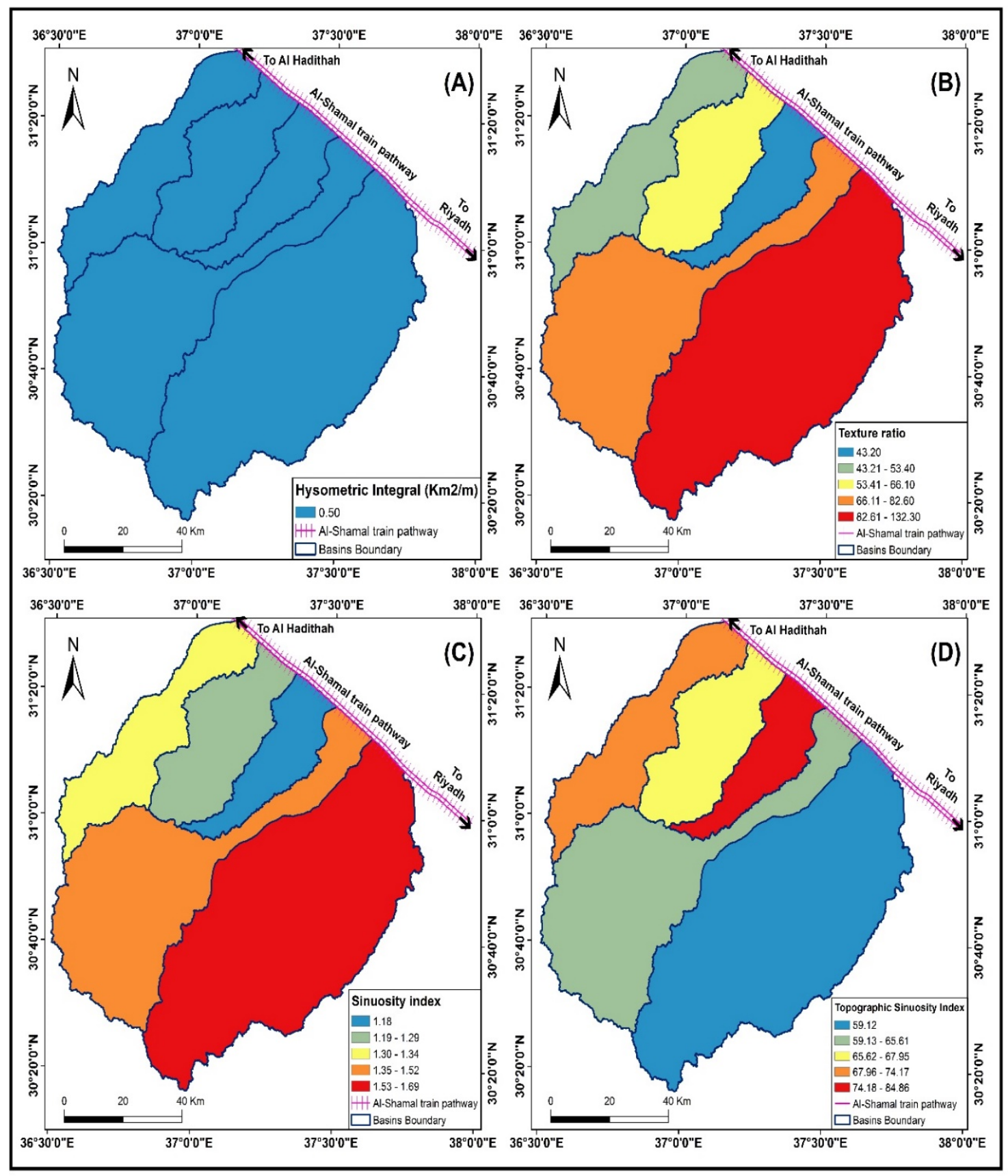

Figure 13. Geomorphometric criteria: (A) hypsometric integral; (B) texture ratio; (C) sinuosity index; (D) topographic sinuosity index.

\section{Stream Frequency}

Stream frequency is defined as the ratio between the total number of tributaries in a drainage basin and the area of the drainage basin. The frequency of the tributaries indicates relief, intrusion rates, and permeability, and has a direct relationship with the drainage density $[62,63,67]$. Stream frequency depends on the structure of the rocks and the type of vegetation. Drainage basins containing dense forests and tributaries with a solid geological structure appear in drainage networks with low stream frequency. Conversely, drainage basins that contain agricultural land and weak geological structures have high stream frequency [68]. The frequency of the tributaries for the drainage sub-basins affecting the Al-Shamal train line ranges from 12.27 streams $/ \mathrm{km}^{2}$ in the basin of Hasidah Umm Nakhla to 13.61 streams $/ \mathrm{km}^{2}$ in the basin of Bayer. 


\section{Drainage Density}

Drainage density is defined as the ratio between the lengths of all tributaries in a drainage basin and the area of the drainage basin. The drainage density refers to relief, geology, extent of soil erosion, and water drainage $[63,69]$. Higher values of drainage density indicate steep slopes [70] with semipermeable solid geology, rough texture, and favorable conditions for groundwater conservation [69,71]. The density of the water discharge of the drainage sub-basins affecting the Al-Shamal train line ranges between $3.81 \mathrm{~km} / \mathrm{km}^{2}$ in the basin of Hasidah Umm Nakhla and $3.93 \mathrm{~km} / \mathrm{km}^{2}$ in the basin of Makhrouq.

\section{Bifurcation Ratio}

The bifurcation ratio is defined as the ratio between the total number of tributaries in a particular order and the total number of the tributaries in the next order $[63,66]$. The bifurcation rate indicates the shape of the basin and the response to erosion, in addition to the geological structure of the area. A higher bifurcation rate represents a rectangular basin and a high erosion rate, whereas a lower bifurcation rate represents a circular basin and a low erosion rate [62,71]. The bifurcation ratios of the drainage sub-basins that affect the Al-Shamal train line range between 1.57 in the basins of Makhrouq and Hasidah Algharbya, and 7.49 in the basin of Hasidah Umm Nakhla.

\section{Weighted Mean Bifurcation Ratio}

The weighted mean bifurcation ratio is more accurate than the bifurcation ratio, as it takes into account the numbers of tributaries in each stream order in the drainage basin. This ratio is more likely to be consistent than the bifurcation ratio $[63,66]$. Higher values of the bifurcation ratio represent a rectangular basin and a high erosion rate, while lower bifurcation ratio values represent a circular basin and a low erosion rate $[62,66]$. The weighted mean bifurcation ratios of the drainage sub-basins affecting the Al-Shamal train line range from 3 in the basin of Makhrouq to 3.92 in the basin of Hasidah Umm Nakhla.

\section{Circularity Ratio}

The circularity ratio is defined as the ratio between the area of the drainage basin and the square of the basin circumference to a fixed value (12.57), and indicates that the basin has a circular shape. The circularity ratio denotes the form parameters [64], rates of discharge and erosion [66], and the geomorphological and relief features [58]. The circularity ratio is influenced by other factors such as lengths and frequency of tributaries, geological structure, land uses, climate, relief, and basin slope $[63,65,72]$. The circularity ratio for drainage sub-basins affecting the Al-Shamal train line ranges from 0.15 in the basin of Makhrouq to 0.26 in the basin of Sarmadaa.

\section{Elongation Ratio}

The elongation ratio is defined as the ratio between the length of a circle's diameter with the same area of the basin and the length of the basin, and indicates a rectangular basin shape. The elongation ratio indicates the form parameters, the erosion rate, intrusion, and runoff. Higher values of the elongation ratio indicate significant erosion, intrusion, and low runoff $[62,65,68]$. The elongation ratio of the drainage sub-basins affecting the Al-Shamal train line range between 0.22 in the basin of Makhrouq and 0.32 in the basins of Hasidah Algharbya and Sarmadaa.

\section{Basin Perimeter}

The basin perimeter of a drainage basin is defined as the ratio between the area of a basin and its perimeter. The basin perimeter indicates the length of the outer limits of the drainage basin relative to the area and thus determines other geomorphometric factors such as volume, shape, and drainage density. The upper values of the basin perimeter indicate a large basin size, a lower perimeter, and a high drainage density [52]. The basin perimeters of the subdrainage basins affecting the Al-Shamal train line range from $3.5 \mathrm{~km}$ in the basin of Hasidah Umm Nakhla to $9.9 \mathrm{~km}$ in the basin of Sarmadaa. 


\section{Mean Basin Width}

The mean basin width determines the permissible amplitude of the basin branches, and the dividing line represents its start and end [62]. Mean basin width refers to morphological parameters such as basin form, form factor, and elongation ratio. The lower value of the mean basin width indicates a rectangular basin shape and a greater elongation ratio $[62,63]$. The average width of the drainage sub-basins affecting the Al-Shamal train line ranges from $12.9 \mathrm{~km}$ in the basin of Hasidah Umm Nakhla to $38.6 \mathrm{~km}$ in the basin of Sarmadaa.

\section{Form Factor}

The form factor is defined as the ratio between the area of the drainage basin and the square of the length of the basin. The form factor indicates the shape, volume, and length of the basin. Rectangular drainage basins are represented by a lower value for the form factor parameter, whereas round drainage basins are represented by a higher value for the form factor [61]. The form factor for the sub-basins affecting the Al-Shamal train line range from 0.19 in the basin of Bayer to 0.33 in the basin of Hasidah Algharbya.

\section{Compactness Coefficient}

The compactness coefficient is defined as the ratio between the circumference of the basin and the circumference of a circle that has an area equal to the drainage area of the same basin. The compactness coefficient indicates the erosion rate, in which higher compactness coefficient values indicate significant erosion rates. The compactness coefficient depends on the volume and slope of the drainage basins [66]. The compactness coefficient of the drainage sub-basins affecting the Al-Shamal train line range between 2.0 in the basins of Hasidah Algharbya and Sarmadaa to 2.6 in the basin of Makhrouq.

\section{Lemniscate Factor}

The shape of the drainage area is wide in the upper basin and gradually narrows towards the lower basin. Chorleye proposed the lemniscate factor to express this geometrical characteristic of drainage basins. The lemniscate factor is defined as the ratio between the square of the basin length and four times the area of the basin. The lemniscate factor of the drainage sub-basins affecting the Al-Shamal train line ranges from 0.76 in the basin of Hasidah Algharbya to 1.61 in the basin of Makhrouq.

\section{Wandering Ratio}

The wandering ratio is defined as the ratio between the length of the main stream that represents the distance the water travels from the source to the promontry, and the ideal length of the stream that represents the shortest distance from the source to the promontory.The wandering ratio indicates the extent of erosion, the geological composition, and the surface runoff speed. Higher values of the wandering ratio represent a high erosion rate, weak geological structure, and low surface runoff speed $[61,62]$. The wandering ratio at the drainage sub-basins that affect the Al-Shamal train line ranges between 1.2 in the basin of Hasidah Umm Nakhla and 1.7 in the basin of Sarmadaa.

\section{Hypsometric Integral}

The hypsometric integral is defined as the ratio between the average difference between the mean and the lowest depths, and the relief range. The hypsometric integral represents a time scale that expresses a phase though which the wadis of the rivers pass. The value of the hypsometric integral of all the drainage sub-basins affecting the Al-Shamal train line is a constant value equal to $50 \mathrm{~km}^{2} / \mathrm{m}$. 
Texture ratio is defined as the ratio between the total number of tributaries and the basin perimeter. The average of the texture refers to the amount and speed of runoff [64]. Higher values of the texture ratio indicate surface degradation and, therefore, slow surface runoff and increased intrusion rate [64]. The average of the texture ratio for the drainage sub-basins affecting the Al-Shamal train line range from 43.2 in the basin of Hasidah Umm Nakhla to 132.3 in the basin of Sarmadaa.

XXIII. Sinuosity Index

The sinuosity index is defined as the ratio between the length of the main stream that represents the distance the water travels from the source to the promontory and the length of the basin. The sinuosity index indicates the extent of the responses to erosion, the geological composition of the area, and the speed of runoff. Higher values of the sinuosity index represent a large erosion rate, weak geological structure, and low runoff speed [62,71]. The sinuosity index of the drainage sub-basins affecting the Al-Shamal train line range between 1.18 in the basin of Hasidah Umm Nakhla and 1.69 in the basin of Sarmadaa.

XXIV. Topographic Sinuosity Index

Topographic sinuosity index is defined as the share, expressed as a percentage, of the length of the drainage basin subtracted from one to the length of the main stream that represents the distance the water travels from the source to the promontory subtracted from one. The topographical sinuosity index of the drainage sub-basins affecting the Al-Shamal train line range between 59.12 in the basin of Sarmadaa and 84.86 in the basin of Hasidah Umm Nakhla.

\subsection{Flood Hazard Map along the Al-Shamal Train Pathway}

A flood hazard model was used to identify the classes of flood hazard for the drainage sub-basins. Figure 14 and Table 6 indicate that the drainage sub-basins are subject to very high hazard levels, which accounts for an area of about $4228.3 \mathrm{~km}^{2}$ in the wadis of Bayer and Makhrouq. The geomorphometric number of the total sum of the hazard $\left(=120^{\circ}\right)$ for the 24 geomorphometric criteria is $84.36^{\circ}(70.3 \%)$ in the wadi of Makhrouq and $78.86^{\circ}(65.7 \%)$ in the wadi of Bayer. The geomorphometric number of the wadi of Sarmadaa is $73.2^{\circ}(61 \%)$, with hazard ${ }^{\circ}$ ranging from 72.944 to 78.652 , and an area equivalent to $4712.4 \mathrm{~km}^{2}$.

Table 6. Flood hazard classes along the Al-Shamal train line.

\begin{tabular}{ccc}
\hline Class & Range & Degree of Hazards \\
\hline First & $55.82-61.528$ & Very low \\
Second & $61.528-67.236$ & Low \\
Third & $67.236-72.944$ & Medium \\
Fourth & $72.944-78.652$ & High \\
Fifth & $78.652-84.36$ & Very high \\
\hline
\end{tabular}

The wadi of Hasidah Algharbya is subject to flood hazards ranging from $67.236^{\circ}$ to $72.944^{\circ}$ with an area of $1271.3 \mathrm{~km}^{2}$. Furthermore, the geomorphometric number was 69.18 , accounting for about $57.7 \%$. The wadi of Hasidah Umm Nakhla is subject to flood hazards ranging from 55.82 to $61.528^{\circ}$ with an area of $799.4 \mathrm{~km}^{2}$; the geomorphometric number was 55.82 , accounting for about $46.5 \%$. 




Figure 14. Flood hazards of drainage basins affecting the Al-Shamal train line.

\subsection{Matrix Correlation}

Approximately 300 correlation relationships exist between the 24 geomorphometric criteria parameters. Of these, $86(28.7 \%)$ were very weak relationships, with a coefficient of determination ranging from 0 to $0.1 ; 72(24 \%)$ were weak relationships, with a coefficient of determination ranging from 0.1 to $0.35 ; 46(15.3 \%)$ were mean relationships, with a coefficient of determination of $0.35-0.65$; $42(14 \%)$ were strong relationships, with a coefficient of determination ranging from 0.65 to 0.9 ; and $54(18 \%)$ were very strong relationships, with a coefficient of determination ranging from 0.9 to 1 . Figure 15 shows the correlation matrix for the geomorphological criteria based on the value of $R^{2}$.

\subsection{Validation of Flood Hazard Model}

The ROC curve method is a statistical method based on a scientific and mathematical basis that provides a graphical representation and allows the accuracy and reliability of the flood hazard map to be evaluated [72-74]. The ROC curve is a graph of two axes ( $x$ and $y$ ). The false-positive rate (FPR) is displayed along the $x$-axis. The FPR is a rate that expresses the number of samples in the flood hazard map that are classified as having a low likelihood of flooding occurring, in which no flooding has occurred previously. The true positive rate (TPR) is displayed along the $y$-axis. This rate expresses the number of samples in the flood hazard map in which flooding is classified as likely to occur, and in which flooding has occurred previously. 


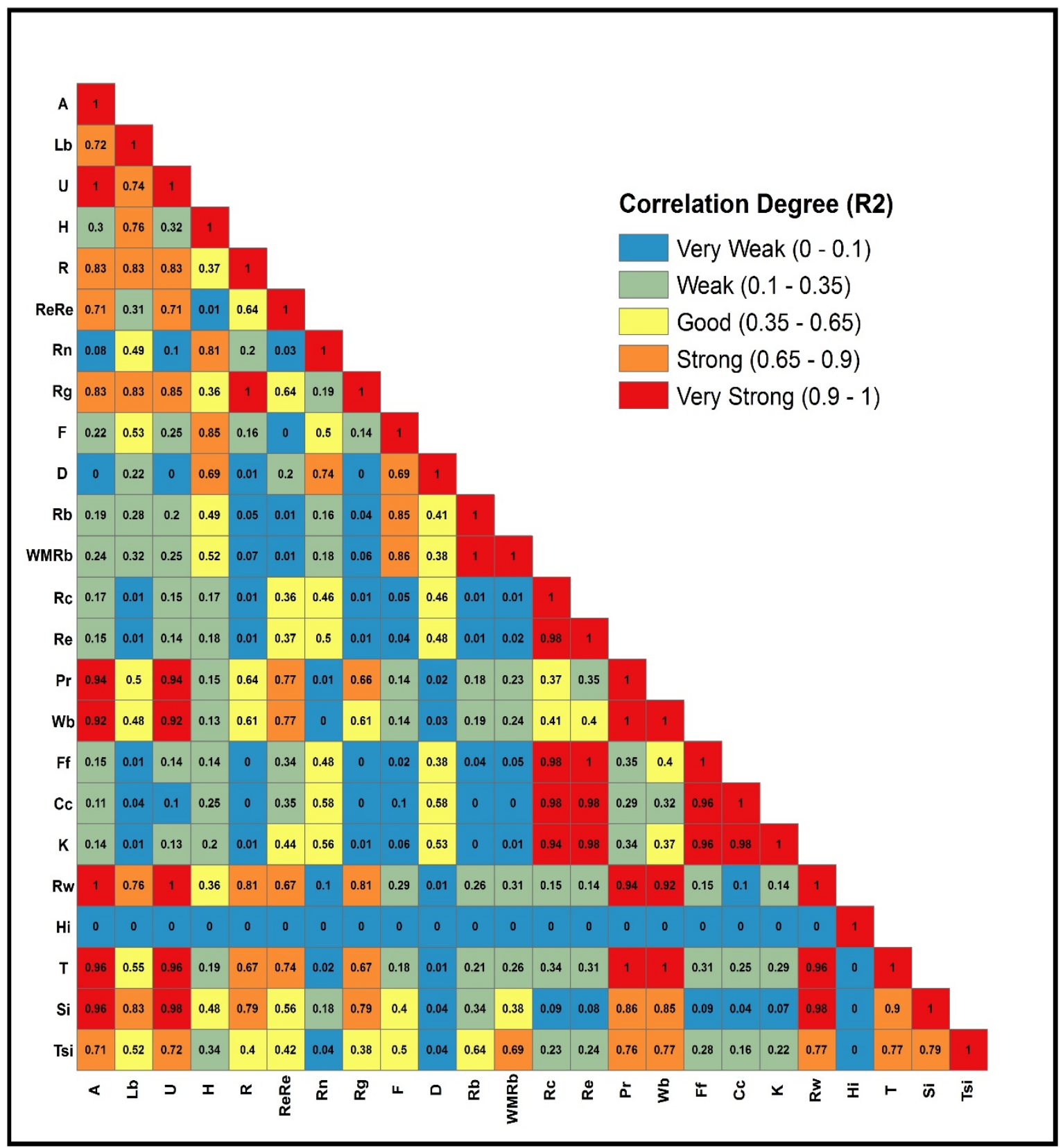

Figure 15. Matrix of correlation between the geomorphological criteria based on the $\mathrm{R}^{2}$ value.

The area under the curve (AUC) was used to examine the reliability of the prediction rate. If the AUC was less 0.5 (AUC < 0.5), then the results of the flood risk map cannot be completely relied upon because they are deemed to be misleading or incorrect. In contrast, if $A U C=1$, then the results are ideal and thus appropriate. Table 7 shows the AUC and the degree of validation of the results.

Table 7. Area under the curve (AUC) values and the degree of validation of the results.

\begin{tabular}{cc}
\hline AUC & Degree of Validation \\
\hline$<0.5$ & The results cannot be relied upon \\
$0.5-0.6$ & Weak \\
$0.6-0.7$ & Medium \\
$0.7-0.8$ & good \\
$0.8-0.9$ & Very good \\
$0.9-1$ & Excellent \\
\hline
\end{tabular}


The ROC curve was drawn between the values extracted from the flood map of the samples, which were selected from the field study of the region. Figure 16 shows the flood of the wadi of Bayer and the resulting severe damage in the villages of Ghati and Bayer on 10 November 2018. The ROC curve presented in Figure 17 was obtained using the SPSS software. The AUC value was 0.971 (97.1\%) with a confidence level of $95 \%$; this value indicates the obtained flood hazard map has an excellent degree of reliability.
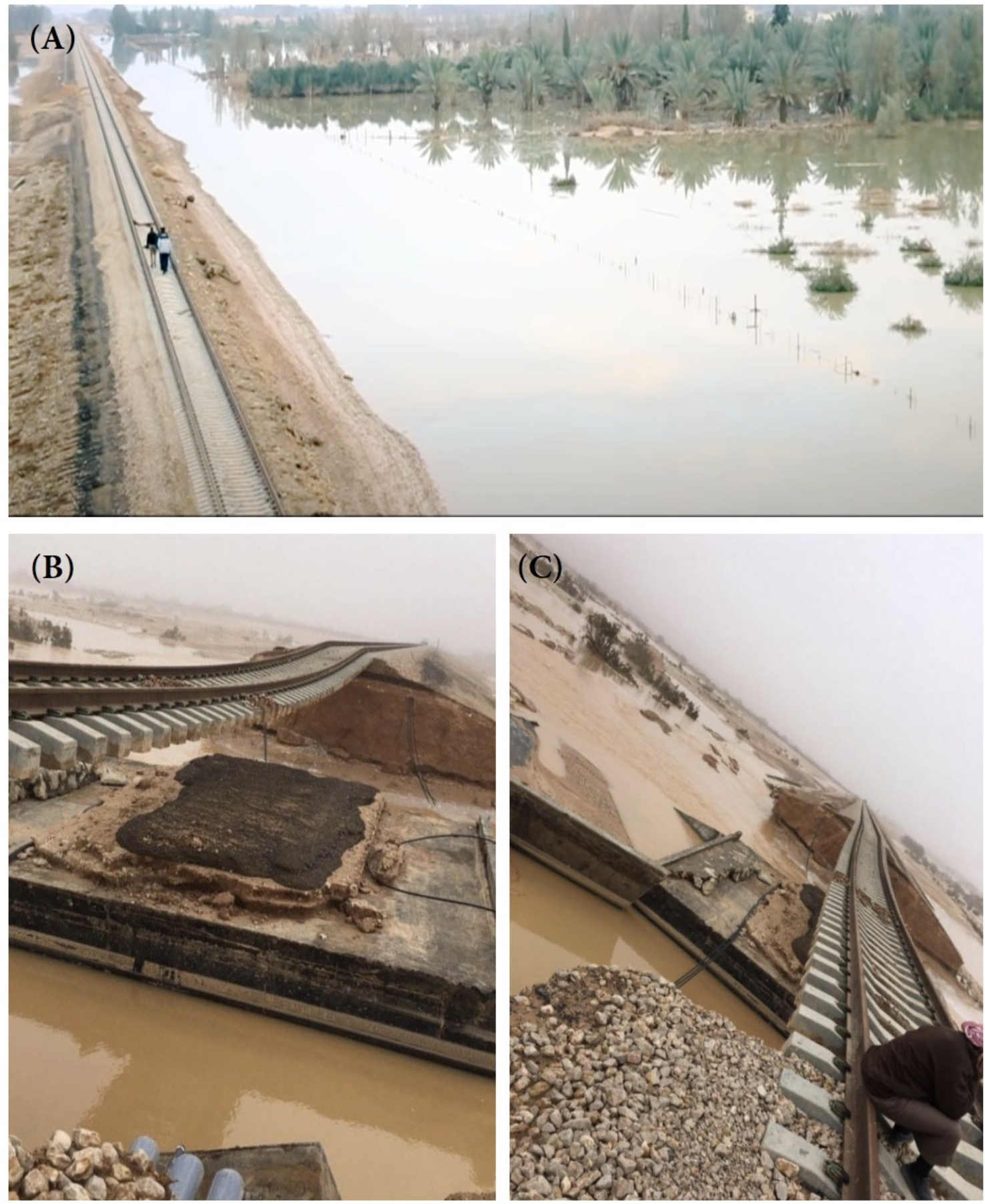

Figure 16. (A) Flooding of the villages of Bayer and Ghati on 10 November 2018. (B,C) Damage to the Al-Shamal train line due to flooding in the wadi of Bayer on 10 November 2018. 
ROC Curve

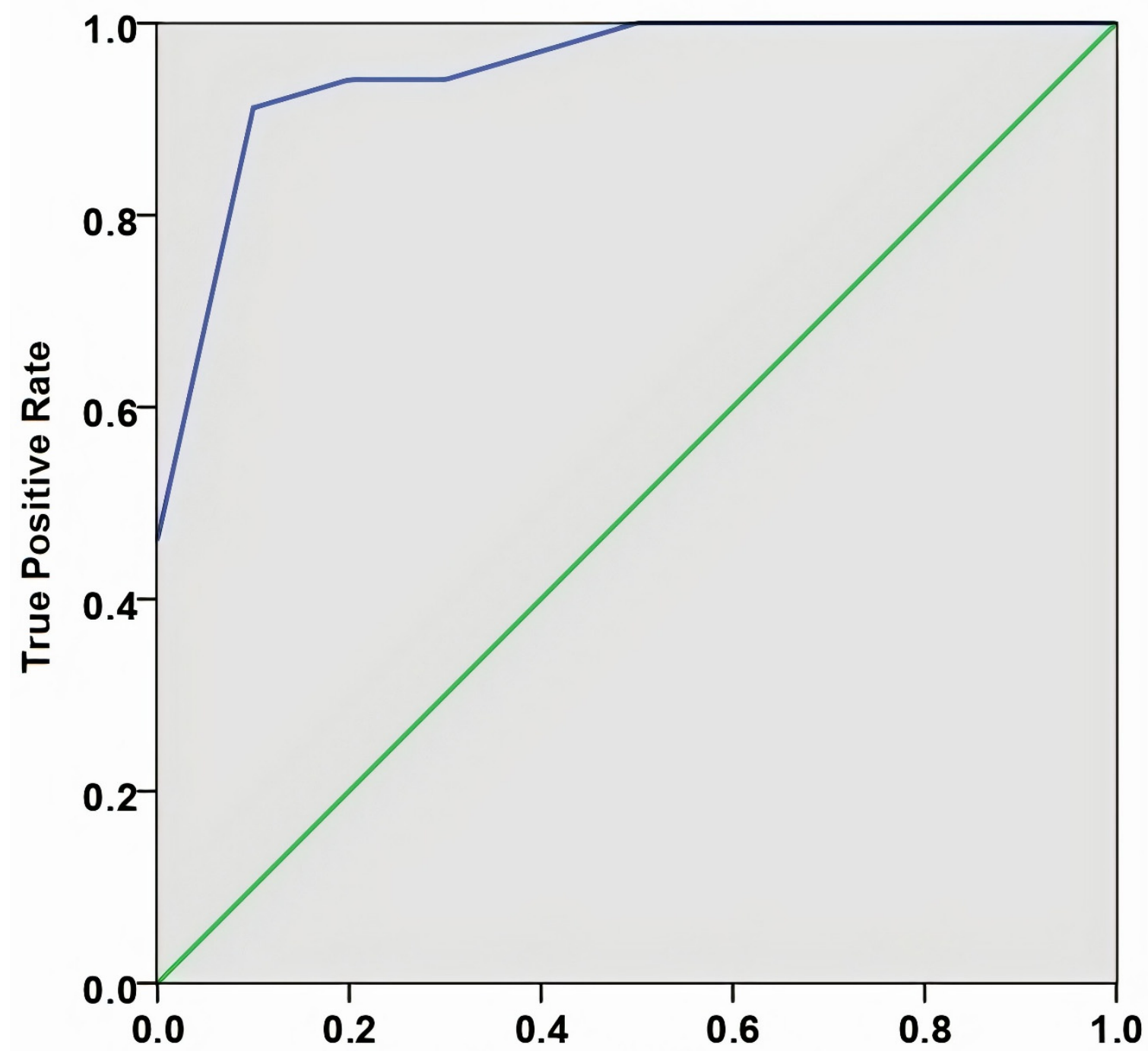

Figure 17. ROC curve between the values extracted from the sample flood map and the hazard classification values.

\section{Conclusions and Recommendations}

This study inspected the impacts of flood hazards on the Al-Shamal train line in the city of Qurayyat, Saudi Arabia, based on the integration of GIS and the hazard model of geomorphological ranking. The obtained flood hazard map is an essential component in emergency planning, flood forecasting, land planning, and resource allocation. The study examined five main wadis, namely, Makhrouq, Hasidah Algharbya, Hasidah Umm Nakhla, Bayer, and Sarmadaa. These wadis carry millions of cubic meters of floodwater each year, which provides no benefit, in addition to causing destruction of infrastructure. Implementation of projects to mitigate the flood hazard is lacking, particularly in the wadis examined in this study.

The results indicated that there were four classes of flood hazard along the Al-Shamal train line in the city of Qurayyat, namely, very high, high, medium, and very low. The very high hazards were focused on the drainage basins of the wadis of Makhrouq and Bayer, accounting for nearly $70.3 \%$ and $65.7 \%$, respectively, and a total area of $4228.3 \mathrm{~km}^{2}$. The high hazards were represented in the wadi of the Sarmadaa basin, accounting for $61 \%$ and an area of $4712.4 \mathrm{~km}^{2}$. The medium hazards were centralized in the wadi of Hasidah Algharbya, accounting for about $57.7 \%$ and an area of $1271.3 \mathrm{~km}^{2}$. 
The very low hazards were represented in the wadi of Hasidah Umm Nakhla, accounting for $46.5 \%$ and an area of $799.4 \mathrm{~km}^{2}$.

The study area urgently requires further research on the application of integrated strategies to mitigate flood hazards. These studies should begin by focusing on the wadis affecting the study area, namely, Makhrouq, Bayer, Hasidah Algharbya, Hasidah Umm Nakhla, and Sarmadaa. Additional hydrological studies are required to estimate the maximum flow of floodwaters and their arrival time based on the amount of rainfall occurring in these wadis at the different reference periods of 50 and 100 years. In addition, further research is critical for the construction of drainage facilities for floodwater and the establishment of appropriate protection measures, according to the research findings.

The results of the flood hazard map obtained in this study indicate a pressing need for a plan to be implemented to mitigate flood hazards. Priority must be given to areas that are classified as high and very high flood hazard, particularly in the wadis of Bayer and Makhrouq, and the point where these wadis converge with the Al-Shamal train line. These areas have been subject to repeated flood hazards and, consequently, the inhabitants of the villages of Bayer, Ghati, and Hasidah have been displaced. Furthermore, the study recommends directing future urban growth and infrastructure away from the areas referred to in the flood hazard map, particularly areas classified as having high and very high hazards. In addition, construction in agricultural areas without providing suitable measures to mitigate flood hazards commensurate with the surface runoff of the wadis should also be avoided or prohibited.

This study recommends implementation of a long-term plan to address the most critical regions of the study area; these are: north of the city of Qurayyat, in the area of Faidha Rashrashiyeh; northwest of the city of Qurayyat along the new international road; the villages of Aqeelah and Dabousieh; the villages of Bayer and Ghati; and the villages of Ain Hawas. The company that owns the Al-Shamal train line project should reconsider the suitability of the location of the line, which extends $2750 \mathrm{~km}$ from Riyadh in the south to Hasidah in the north. Moreover, the company should undertake hazard studies encompassing flooding, geomorphological hazards, and sand migration to ensure the safety of life and property. The current research concentrated on the drainage basins in the city of Qurayyat. However, the same approach can be implemented in other dry drainage basins in arid and semiarid environments. The obtained results are expected to be valuable for planners to apply suitable protection measures and develop early warning systems against flood hazards.

Author Contributions: A.A. designed the study, developed the research idea, and planned the research activities, designed the methodology, replied to the reviewer's comments; wrote the manuscript, and professionally edited the manuscript; S.S.A.-A. performed climatic and statistical criteria analysis; H.M.A. contributed the geological and hydrological criteria; S.A.M. developed the research methodology and wrote and reviewed the manuscript; I.I.A. and I.Y.Y. carried out statistical and spatial analyses for monitoring the changes in land use and provided valuable comments in writing this paper; and A.A., S.S.A.-A., H.M.A., S.A.M., I.I.A., and I.Y.Y. carried out the research, including collecting the input data, preparing the manuscript, and carrying out a statistical analysis of the obtained results. All authors have read and agreed to the published version of the manuscript.

Funding: This work was funded by the Deanship of Scientific Research at Princess Nourah bint Abdulrahman University, through the Research Groups Program Grant No. (RGP-1440-0029).

Acknowledgments: The authors highly appreciate the great support from the Deanship of Scientific Research at Princess Nourah bint Abdulrahman University, Grant No. (RGP-1440-0029).

Conflicts of Interest: The authors declare no conflict of interest.

\section{References}

1. Opdam, P.; Wascher, D. Climate change meets habitat fragmentation: Linking landscape and biogeographical scale levels in research and conservation. Boil. Conserv. 2004, 117, 285-297. [CrossRef]

2. Kostopoulou, E.; Jones, P.D. Assessment of climate extremes in the Eastern Mediterranean. Theor. Appl. Clim. 2005, 89, 69-85. [CrossRef] 
3. Thieken, A.; Kienzler, S.; Kreibich, H.; Kuhlicke, C.; Kunz, M.; M, T.A.; Otto, A.; Petrow, T.; Pisi, S.; Schröter, K. Review of the flood risk management system in Germany after the major flood in 2013. Ecol. Soc. 2016, 21, 1-12. [CrossRef]

4. Nijland, H. Sustainable development of floodplains (SDF) project. Environ. Sci. Policy 2005, 8, $245-252$. [CrossRef]

5. Abdel-Fattah, M.; Saber, M.; Kantoush, S.A.; Khalil, M.F.; Sumi, T.; Sefelnasr, A. A Hydrological and Geomorphometric Approach to Understanding the Generation of Wadi Flash Floods. Water 2017, 9, 553. [CrossRef]

6. Abdelkarim, A.; Gaber, A.F.D.; Youssef, A.M.; Pradhan, B.; Youssef, A.M. Flood Hazard Assessment of the Urban Area of Tabuk City, Kingdom of Saudi Arabia by Integrating Spatial-Based Hydrologic and Hydrodynamic Modeling. Sensors 2019, 19, 1024. [CrossRef] [PubMed]

7. Pike, R.J. A Bibliography of Terrain Modeling (Geomorphometry), the Quantitative Representation of Topography—Supplement 4.0; U.S. Geological Survey: Washington, DC, USA, 2002; pp. 1-158. Available online: https://pubs.usgs.gov/of/2002/0465/pdf/of02-465.pdf (accessed on 4 June 2020).

8. Argyriou, A.; Teeuw, R.; Sarris, A. GIS-based landform classification of Bronze Age archaeological sites on Crete Island. PLoS ONE 2017, 12, e0170727. [CrossRef] [PubMed]

9. Abdelkarim, A.; Gaber, A.F.D.; Alkadi, I.I.; Alogayell, H.M. Integrating Remote Sensing and Hydrologic Modeling to Assess the Impact of Land-Use Changes on the Increase of Flood Risk: A Case Study of the Riyadh-Dammam Train Track, Saudi Arabia. Sustainability 2019, 11, 6003. [CrossRef]

10. Ez Eldeen, F. Topography problems in the Eastern desert Egypt, and their impacts on the roads, Quantitative and analytical study. Bull. Geog. Soc. Egypt 1989, 21, 79-108. (In Arabic)

11. Pradhan, B.; Lee, S. Landslide susceptibility assessment and factor effect analysis: Backpropagation artificial neural networks and their comparison with frequency ratio and bivariate logistic regression modelling. Environ. Model. Softw. 2010, 25, 747-759. [CrossRef]

12. Pradhan, B. Flood susceptible mapping and risk area delineation using logistic regression, GIS and remote sensing. J. Spat. Hydrol. 2009, 9, 1-19.

13. Visher, G.S. Fluvial Processes as Interpreted from Ancient and Recent Fluvial Deposits. In Primary Sedimentary Structures and Their Hydrodynamic Interpretation; Society for Sedimentary Geology: Tulsa, OK, USA, 1965; Volume 12, pp. 116-132.

14. Raja, D.L. Morphometric and Land Use Analysis to Estimate Flood Hazard - A Case Study of Upper Cimanuk Watershed in Garut Regency, Indonesia. Int. J. GEOMATE 2020, 19, 126-133. [CrossRef]

15. Charizopoulos, N.; Mourtzios, P.; Psilovikos, T.; Psilovikos, A.; Karamoutsou, L. Morphometric analysis of the drainage network of Samos Island (northern Aegean Sea): Insights into tectonic control and flood hazards. Comptes Rendus Geosci. 2019, 351, 375-383. [CrossRef]

16. Alfa, M.; Ajibike, M.; Adie, D.; Mudiare, O. Hydrologic and morphometric analysis of Ofu River Sub-Basin using remote sensing and Geographic Information System. Niger. J. Technol. Dev. 2019, 16, 49. [CrossRef]

17. Muralitharan, J.; Palanivel, K. Sub-watershed wise Runoff Modeling using Drainage Morphometric Analysis in Karur District, Tamil Nadu, India through Remote Sensing and GIS Techniques. J. Remote Sens. GIS 2019, 10, 52-65. [CrossRef]

18. Elsadek, W.M.; Ibrahim, M.G.; Mahmod, W.E. Runoff hazard analysis of Wadi Qena Watershed, Egypt based on GIS and remote sensing approach. Alex. Eng. J. 2019, 58, 377-385. [CrossRef]

19. Pourghasemi, H.R.; Pradhan, B.; Gokceoglu, C. Application of fuzzy logic and analytical hierarchy process (AHP) to landslide susceptibility mapping at Haraz watershed, Iran. Nat. Hazards 2012, 63, 965-996. [CrossRef]

20. Rozos, D.; Bathrellos, G.; Skillodimou, H.D. Comparison of the implementation of rock engineering system and analytic hierarchy process methods, upon landslide susceptibility mapping, using GIS: A case study from the Eastern Achaia County of Peloponnesus, Greece. Environ. Earth Sci. 2010, 63, 49-63. [CrossRef]

21. Valverde, J.P.B.; Blank, C.; Roidt, M.; Schneider, L.; Stefan, C. Application of a GIS Multi-Criteria Decision Analysis for the Identification of Intrinsic Suitable Sites in Costa Rica for the Application of Managed Aquifer Recharge (MAR) through Spreading Methods. Water 2016, 8, 391. [CrossRef]

22. Khosravi, K.; Nohani, E.; Maroufinia, E.; Pourghasemi, H.R. A GIS-based flood susceptibility assessment and its mapping in Iran: A comparison between frequency ratio and weights-of-evidence bivariate statistical models with multi-criteria decision-making technique. Nat. Hazards 2016, 83, 947-987. [CrossRef] 
23. Patrikaki, O.; Kazakis, N.; Kougias, I.; Patsialis, T.; Theodossiou, N.; Voudouris, K. Assessing Flood Hazard at River Basin Scale with an Index-Based Approach: The Case of Mouriki, Greece. Geosciences 2018, 8, 50. [CrossRef]

24. Gigović, L.; Pamučar, D.; Bajić, Z.; Drobnjak, S. Application of GIS-Interval Rough AHP Methodology for Flood Hazard Mapping in Urban Areas. Water 2017, 9, 360. [CrossRef]

25. Ajjur, S.B.; Mogheir, Y.K. Flood hazard mapping using a multi-criteria decision analysis and GIS (case study Gaza Governorate, Palestine). Arab. J. Geosci. 2020, 13, 44. [CrossRef]

26. Cabrera, J.S.; Lee, H.S. Flood risk assessment for Davao Oriental in the Philippines using geographic information system-based multi-criteria analysis and the maximum entropy model. J. Flood Risk Manag. 2020, 13, e12607. [CrossRef]

27. Costache, R.; Pham, Q.B.; Sharifi, E.; Linh, N.T.T.; Abba, S.I.; Vojtek, M.; Vojteková, J.; Nhi, P.T.T.; Khoi, D.N.; Khoi, D.N. Flash-Flood Susceptibility Assessment Using Multi-Criteria Decision Making and Machine Learning Supported by Remote Sensing and GIS Techniques. Remote. Sens. 2019, 12, 106. [CrossRef]

28. Wibowo, R.C.; Sarkowi, M.; Setiawan, A.F.; Yudamson, A.; Asrafil; Kurniawan, M.; Arifianto, I. Flash flood hazard areas assessment in Bandar Negeri Suoh (BNS) region using an index based approaches and analytical hierarchy process. J. Physics: Conf. Ser. 2020, 1434, 012006. [CrossRef]

29. Dano, U.L. Flash Flood Impact Assessment in Jeddah City: An Analytic Hierarchy Process Approach. Hydrology 2020, 7, 10. [CrossRef]

30. Abdelkarim, A.; Al-Alola, S.S.; Alogayell, H.M.; Mohamed, S.A.; Alkadi, I.I.; Ismail, I.Y. Integration of GIS-Based Multicriteria Decision Analysis and Analytic Hierarchy Process to Assess Flood Hazard on the Al-Shamal Train Pathway in Al-Qurayyat Region, Kingdom of Saudi Arabia. Water 2020, 12, 1702. [CrossRef]

31. The central Valley floodplain Evaluation Delineation program (CVFED), Guidelines for Applying the FLO-2D Model to The central Valley floodplain Evaluation Delineation Program. 2009, pp. 1-61. Available online: https://www.scribd.com/document/227411177/CVFED-FLO-2D-Project-Guidelines (accessed on 20 July 2020).

32. Meghan, A.; Christophe, V.; Hazel, F.; Sally, P. Methods for Creating a Flood Risk Assessment Tool; Middlesex University, Flood Hazard Research Center (fhrc): London, UK, 2011; pp. 6-58.

33. Al-Zahrani, M.; Al-Areeq, A.; Sharif, H.O. Estimating urban flooding potential near the outlet of an arid catchment in Saudi Arabia. Geomatics, Nat. Hazards Risk 2016, 8, 672-688. [CrossRef]

34. Bates, P.D.; De Roo, A. A simple raster-based model for flood inundation simulation. J. Hydrol. 2000, 236, 54-77. [CrossRef]

35. Rahmati, O.; Darabi, H.; Haghighi, A.T.; Stefanidis, S.; Kornejady, A.; Nalivan, O.A.; Bui, D.T. Bui Urban Flood Hazard Modeling Using Self-Organizing Map Neural Network. Water 2019, 11, 2370. [CrossRef]

36. Petroselli, A.; Vojtek, M.; Vojteková, J. Flood mapping in small ungauged basins: A comparison of different approaches for two case studies in Slovakia. Hydrol. Res. 2018, 50, 379-392. [CrossRef]

37. Elkarim, A.A. Intergration Remote Sensing and Hydrologic, Hydroulic Modelling on Assessment Flood Risk and Mitigation: Al-Lith City, KSA. Int. J. GEOMATE 2020, 18, 252-280. [CrossRef]

38. Abdelkarim, A.; Gaber, A.F.D. Flood Risk Assessment of the Wadi Nu'man Basin, Mecca, Saudi Arabia (During the Period, 1988-2019) Based on the Integration of Geomatics and Hydraulic Modeling: A Case Study. Water 2019, 11, 1887. [CrossRef]

39. Liu, Z.; Merwade, V.; Jafarzadegan, K. Investigating the role of model structure and surface roughness in generating flood inundation extents using one- and two-dimensional hydraulic models. J. Flood Risk Manag. 2018, 12, e12347. [CrossRef]

40. Davis, J.C. Statics and Data Analysis in Geology; Wiley: New York, NY, USA, 1975.

41. Toy, T.; Hadley, F. Geomorphology and Reclamation of Distributed Lands; John Wiley and Sons: New York, NY, USA, 1987; pp. 289-343.

42. Bajabaa, S.; Masoud, M.H.; Al-Amri, N. Flash flood hazard mapping based on quantitative hydrology, geomorphology and GIS techniques (case study of Wadi Al Lith, Saudi Arabia). Arab. J. Geosci. 2013, 7, 2469-2481. [CrossRef]

43. Yousif, M.; Bubenzer, O. Geoinformatics application for assessing the potential of rainwater harvesting in arid regions. Case study: El Daba'a area, Northwestern Coast of Egypt. Arab. J. Geosci. 2015, 8, 9169-9191. [CrossRef] 
44. Farhan, Y.; Ayed, A. Assessment of Flash-Flood Hazard in Arid Watersheds of Jordan. J. Geogr. Inf. Syst. 2017, 9, 717-751. [CrossRef]

45. Liu, J.; Xu, Z.; Chen, F.; Chen, F.; Zhang, L. Flood Hazard Mapping and Assessment on the Angkor World Heritage Site, Cambodia. Remote. Sens. 2019, 11, 98. [CrossRef]

46. Hajian, F.; Dykes, A.P.; Cavanagh, S. Assessment of the flood hazard arising from land use change in a forested catchment in northern Iran. J. Flood Risk Manag. 2018, 12, e12481. [CrossRef]

47. Bathrellos, G.; Karymbalis, E.; Skilodimou, H.D.; Gaki-Papanastassiou, K.; Baltas, E. Urban flood hazard assessment in the basin of Athens Metropolitan city, Greece. Environ. Earth Sci. 2016, 75, 1-14. [CrossRef]

48. Bathrellos, G.; Skilodimou, H.D.; Chousianitis, K.; Youssef, A.M.; Pradhan, B. Suitability estimation for urban development using multi-hazard assessment map. Sci. Total. Environ. 2017, 575, 119-134. [CrossRef] [PubMed]

49. Altuwaijri, H.A. Morphometric network drainage analysis for railway location: Case study of Saudi Railway Company's project. Arab. J. Geosci. 2019, 12, 1-13. [CrossRef]

50. Follum, M.L.; Tavakoly, A.A.; Niemann, J.D.; Snow, A. AutoRAPID: A Model for Prompt Streamflow Estimation and Flood Inundation Mapping over Regional to Continental Extents. JAWRA J. Am. Water Resour. Assoc. 2016, 53, 280-299. [CrossRef]

51. Rajib, A.; Liu, Z.; Merwade, V.; Tavakoly, A.A.; Follum, M.L. Towards a large-scale locally relevant flood inundation modeling framework using SWAT and LISFLOOD-FP. J. Hydrol. 2020, 581, 124406. [CrossRef]

52. Horton, R.E. Erosional Development of Streams and Their Drainage Basins; Hydrophysical Approach to Quantitative Morphology. GSA Bull. 1945, 56, 275. [CrossRef]

53. Schumm, S.A. Evolution of Drainage Systems and Slopes in Badlands at Perth Amboy, New Jersey. GSA Bull. 1956, 67, 597. [CrossRef]

54. Strahler, A.N. Quantitative analysis of watershed geomorphology. Trans. Am. Geophys. Union 1957, 38, 913-920. [CrossRef]

55. Devi, P.S.; Sree, S.; Raju, K.K.; Srinivasulu, S. Hydrogeomorphological and groundwater prospects of the Pageru river basin by using remote sensing data. Environ. Earth Sci. 2001, 40, 1088-1094. [CrossRef]

56. Horton, R.E. Drainage-basin characteristics. Trans. Am. Geophys. Union 1932, 13, 350-361. [CrossRef]

57. Chorley, R.J. Illustrating the Laws of Morphometry. Geol. Mag. 1957, 94, 140. [CrossRef]

58. Smart, J.S.; Surkan, A.J. The relation between mainstream length and area in drainage basins. Water Resour. Res. 1967, 3, 963-974. [CrossRef]

59. Pike, R.J.; Wilson, S.E. Elevation-Relief Ratio, Hypsometric Integral, and Geomorphic Area-Altitude Analysis. GSA Bull. 1971, 82, 1079. [CrossRef]

60. Mueller, J.E. An Introduction to the Hydraulic and Topographic Sinuosity Indexes 1. Ann. Assoc. Am. Geogr. 1968, 58, 371-385. [CrossRef]

61. Gabale, S.; Pawar, N. Quantitative Morphometric Analysis of Ambil Odha (Rivulet) In Pune, Maharashtra, India. IOSR J. Environ. Sci. Toxicol. Food Technol. 2015, 9, 41-48. [CrossRef]

62. Chitra, C.; Alaguraja, P.; Ganeshkumari, K.; Yuvaraj, D.; Manivel, M. Watershed characteristics of Kundah sub basin using Remote Sensing and GIS techniques. Inter. J. Geomat. Geosci. 2011, 2, 311-335.

63. Pareta, K.; Upasana, P. Quantitative Morphometric Analysis of a Watershed of Yamuna Basin, India using ASTER (DEM) Data and GIS. Inter. J. Geomat. Geosci. 2011, 2, 248-269.

64. Farhan, Y.; Anaba, O.; Salim, A. Morphometric Analysis and Flash Floods Assessment for Drainage Basins of the Ras En Naqb Area, South Jordan Using GIS. J. Geosci. Environ. Prot. 2016, 4, 9-33. [CrossRef]

65. Kaur, M.; Singh, S.; Verma, V.K.; Pateriya, B. Quantitative Geomorphological Analysis \& Land Use/Land Cover Change Detection of Two Sub-Watersheds in NE region of Punjab, India. ISPRS Int. Arch. Photogramm. Remote. Sens. Spat. Inf. Sci. 2014, 9, 371-375. [CrossRef]

66. Iqbal, H.S.M. Watershed Prioritization using Morphometric and Land Use/Land Cover Parameters of Dudhganga Catchment Kashmir Valley India using Spatial Technology. J. Geophys. Remote. Sens. 2014, 3, 1-12. [CrossRef]

67. Singh, V.; Singh, U.C. Basin Morphometry of Maingra River, district Gwalior, Madhya Pradesh, India. Inter. J. Geomat. Geosci. 2011, 1, 891-902.

68. Zende, A.; Nagarajan, R.; Atal, K. Analysis of surface runoff from Yerala River Basin using SCS-CN and GIS. Inter. J. Geomat. Geosci. 2014, 4, 508-516. 
69. Gebremedhin, T.K.; Kibru, T.; Tesfaye, S.; Taye, G. Analysis of Watershed Attributes for Water Resources Management Using GIS: The Case of Chelekot Micro-Watershed, Tigray, Ethiopia. J. Geogr. Inf. Syst. 2015, 7, 177-190. [CrossRef]

70. Vandana, M. Morphometric analysis watershed prioritization: A case study of Kabani river basin, Wayanad district, Kerala, India. Indian J. Geo-Mar. Sci. 2013, 42, 211-222.

71. Khare, D. Morphometric Analysis for Prioritization using Remote Sensing and GIS Techniques in a Hilly Catchment in the State of Uttarakhand, India. Indian J. Sci. Technol. 2014, 7, 1650-1662. [CrossRef]

72. Nandi, A.; Mandal, A.; Wilson, M.; Smith, D. Flood hazard mapping in Jamaica using principal component analysis and logistic regression. Environ. Earth Sci. 2016, 75, 1-16. [CrossRef]

73. Lin, K.; Chen, H.; Xu, C.-Y.; Yan, P.; Lan, T.; Liu, Z.; Dong, C. Assessment of flash flood risk based on improved analytic hierarchy process method and integrated maximum likelihood clustering algorithm. J. Hydrol. 2020, 584, 124696. [CrossRef]

74. Sarkar, D.; Mondal, P. Flood vulnerability mapping using frequency ratio (FR) model: A case study on Kulik river basin, Indo-Bangladesh Barind region. Appl. Water Sci. 2019, 10, 17. [CrossRef]

(C) 2020 by the authors. Licensee MDPI, Basel, Switzerland. This article is an open access article distributed under the terms and conditions of the Creative Commons Attribution (CC BY) license (http://creativecommons.org/licenses/by/4.0/). 